\title{
MÉRNI ANNYI, MINT TUDNI? AZ ELEKTRONIKUS KÖZIGAZGATÁS KÖZÖSSÉGI MÉRŐSZÁMAIRÓL
}

\begin{abstract}
A közszféra kapcsolatrendszereinek az infokommunikációs eszközök által történő átalakítása, a valódi elektronikus közigazgatás megteremtése lassan két évtizede az egyik központi témája az információs társadalom fejlesztési diskurzusainak. A fejlesztési törekvésekkel egyidősek a területet célzó szakpolitikai intézkedések eredményességét, hatásait feltárni igyekvő különböző mérések, mérőszámok. Ahhoz, hogy a mutatók valódi visszacsatolást nyújtsanak a fejlesztők és a döntéshozók számára, az elektronikus közigazgatás értékelésére használatos mérések pontos ismerete szükséges, beleértve azok tágabb kontextusát. A tanulmány, a jelenleg európai viszonylatban legszélesebb körben ismert és használt módszer, az Európai Unió e-közigazgatási értékelőrendszerét igyekszik kritikai módon áttekinteni, Magyarország eredményein keresztül. A szerző kitér a részben ezen felmérés eredményeiből képzett, a legújabb vonatkozó közösségi szakpolitika, a Digitális Menetrend elörehaladását monitorozó, 2015-ben létrehozott mérőszám, a DESI (Digital Economy and Society Index - digitális gazdaság és társadalom index) közigazgatásra vonatkozó pillérének elemzésére is. Az írás célja, hogy a módszertani dokumentumok elemzésével tágabb kontextust teremtsen az eredmények értelmezéséhez, a mérőszámok felhasználásának megfelelő módozataihoz, illetve elősegítse az e-közigazgatási fejlesztések értékeléséről szóló, szélesebb körű hazai párbeszéd kialakulását'.
\end{abstract}

Kulcsszavak: elektronikus közigazgatás, szolgáltatásfejlesztés, mérhetőség, benchmark, digitális gazdaság és társadalom index (DESI)

A mérhetőség, illetve a mérési eredményekre alapozva az embert körbevevő világ kedvező irányba történő megváltoztatása régóta foglalkoztatja az emberiséget. Legalább az 1500-as évekig vezethető vissza a mérés kiemelt fontosságának megfogalmazása (elég, ha a Galileinek tulajdonított ,,mérd meg amit meg tudsz, és tedd mérhetôvé, amit nem” mondásra gondolunk, de pályatársához, Rheticushoz is kötnek ${ }^{2}$ hasonló kijelentést: ,, ha nem tudod megmérni, irányítani sem tudod"), mint elengedhetetlen eszközé a legváltozatosabb célok elérésének érdekében. Később a tudományt középpontba állító felvilágosodás, a racionalitás korszaka, majd a modern természettudományok megszületése és XIX. századi fejlődése ${ }^{3}$ még hangsúlyosabbá tették a mérések fontosságát, amit talán legjobban a kor meghatározó fizikusának, matematikusának - és nem utolsó sorban számos müszer kifejlesztőjének -, Lord Kelvinnek tulajdonított ${ }^{4}$ ars poetica tükröz vissza (,,mérni annyi, mint tudni”). A megközelítés markánsan megjelenik a XX. század második felének menedzsmentirodalmában is (az eredetileg középkori csillagászokhoz kötött, fentebb idézett mondás különböző változatait manapság a menedzsertudományok atyjának tartott Peter Druckernek is tulajdonítják), a folyamatok kontrollálásának, minél kedvezőbb irányba a visszacsatolás módsze- reivel történő folyamatos elmozdításának törekvése számos módszerben öltött testet. Ezek egyike a közismert, W. Edwards Deming (1986) által népszerüsített PDCA-ciklus (Plan - tervezés, Do - cselekvés, Check - ellenörzés, Act - beavatkozás), melynek modernkori alapjait Walter Shewhart (1936) fektette le. A fejlödés eszerint leginkább a folyamatos önreflexió útján, a cselekvések értékelésén, és az értékelésen alapuló változtatással érhető el, amely egy ciklikus folyamat, és beleérthetjük a különböző értékelörendszerek folyamatos átalakítását vagy finomhangolását is a szintén dinamikusan változó környezethez, célokhoz vagy eredményekhez.

Az állam, illetve a közigazgatás működtetése, illetve újraszervezése napjainkban szintén leginkább racionális elvek alapján történik, ami tetten érhető például az új közmenedzsment (New Public Management) paradigmájának megerősödésében is: a közigazgatás müködésével kapcsolatban leginkább a hatékonyság és a szolgáltató jelleg magas szintjének elérése a legföbb elvárás, melynek mérésére a közszolgáltatásokat nyújtó szervezetek esetében számos módszer került megalkotásra (Takács, 2015). Különös jelentőséget ad ezen elvárásoknak való megfelelés során az információs és kommunikációs technológiák robbanásszerű terjedése az elmúlt években, mely döntően

\footnotetext{
${ }^{1}$ A tanulmány a KÖFOP-2.1.2-VEKOP-15-2016-00001 „A jó kormányzást megalapozó közszolgálat-fejlesztés” program Digitális Kormányzás és Digitális Állam Kiemelt Kutatóműhely keretében, annak támogatásával készült.

2 http://www.matthewcornell.org/blog/2007/7/30/whats-your-feed-reading-speed.html\#1

${ }^{3}$ http://www.matud.iif.hu/2012/06/19.htm

${ }^{4}$ Az idézet német változatát egyes források („Messen ist Wissen”) Kelvin kortársához, Werner von Siemenshez is kötik, miközben vannak olyan vélemények is, hogy a közismert idézet ma elterjedt formájában nem is hangzott el, de legalábbis mára már nincs nyoma. https://blog.patientslikeme.com/ openness $/ \%$ e2\% $\% 0 \% 9$ cto-measure-is-to-know $\%$ e $2 \% 80 \% 9 \mathrm{~d} /$
} 
befolyásolja az alapvetően adatközpontúan müködő rendszereket, az élet egyéb területén elérhető alkalmazások (e-kereskedelem, e-bank stb.) elterjedése pedig az állampolgárok elvárásait is növeli az ügyintézéssel kapcsolatban. Ezeknek az elvárásoknak való megfelelés számos új kutatási irányt definiál (lásd például Kemény, 2017, vagy Kenesei - Seprődi, 2017), miközben azt sem szabad szem elöl téveszteni, hogy a közszféra és a versenyszféra szolgáltatásnyújtásában számos különbséget találunk (a kommunikáció területén ennek elemzéséhez lásd Antal, 2018).

A közszféra kapcsolatrendszereinek az infokommunikációs eszközök által történő átalakítása, vagyis az elektronikus közigazgatás (Budai, 2009) fejlesztése szempontjából a fentiek alapján szintén elengedhetetlennek tünik a folyamatos értékelés, ellenőrzés és beavatkozás, így nem meglepő, hogy az ezirányú fejlesztésének kezdeti szakaszától (gyakorlatilag az első kormányzati honlapok megjelenésétől kezdve a '90-es évek második felében) számos különböző módszer ismeretes a közigazgatás digitalizálásának és ezzel összefüggésben e folyamat hatékonyságának monitorozására. Az ezredfordulóra tehető például a ma is használatos, az ENSZ Department of Economic and Social Affairs által végzett, 2008 óta kétévente elkészülő e-közigazgatási felkészültségi felmérés elindulása ${ }^{5}$, de az Európai Unió e-kormányzati „,benchmarkingja"6, azaz a tagországok elektronikus közigazgatással kapcsolatos teljesítményének összehasonlítását lehetővé tevő elemzései szintén a 2000-es évek legelejétől kezdve zajlanak.

A különböző, az elektronikus közigazgatás fejlettségét értékelö, általában nemzetközi megoldásokkal megközelítőleg egyidős ezeknek a mérőrendszereknek a kritikája is. Codagnone és munkatársai (2015) nyomán elmondható, hogy az éppen vizsgált mérőrendszerrel kapcsolatos módszertani erősségeken és gyengeségeken túl gyakori probléma, hogy maguk a méröeszközök ${ }^{7}$ sokszor leszükítő módon az e-közigazgatási szolgáltatások kínálati oldalára (supply side) koncentrálnak. Ez a megközelítés indirekt módon akadályozhatja a valódi hatások (tangible impacts) kimutatását (ami adott esetben a közigazgatási működés és a back-office, azaz a háttérrendszerek érdemi átalakítását jelenti). Az Európai Unió értékelési rendszerében elérhető magas pontszámok sok esetben a szervezetek menedzsmentje által érzékelt minőséget növelik elsősorban (Codagnone et al., 2015), részben abból fakadóan, hogy az értékelörendszer ismeretében olyan fejlesztésekre is ösztönözhet, amelyek az éppen aktuális szempontrendszer szerint ugyan magasabb értékeket eredményeznek, de sem valódi ügyféloldali könnyebbséget nem jelentenek, sem pedig a már említett kapcsolatrendszer érdemi átalakítását nem eredményezik a back-office szintjén. (Szintén elképzelhető forgatókönyv a kínálati oldal olyan egysze- rüsítése, amely érzékelhető eredményekkel jár, ám ezek pluszfeladatokat rónak a háttérrendszerek müködtetőire, vagyis a szolgáltatásnyújtás összteljesítménye nem javul.) Ez a gyakorlat tehát az ,alacsonyan lógó gyümölcsök” elve alapján rövid távon emelheti ugyan egy adott ügytípus esetében az értékelés során kapott pontszámokat, de nem feltétlenül ad választ a tágabb kontextus nyújtotta hosszú távú igényekre és kihívásokra, illetve csak mérsékelten szolgálják a tudás- és adatvezérelt átalakítás (szak) politikai céljainak teljesülését; hosszabb távon pedig elodázhatnak olyan strukturális átalakításokat, amelyek elmaradása konzerválja egy ország kedvezőtlen helyzetét.

A korábbi tapasztalatok azt mutatják tehát, hogy egy értékelésre létrehozott rendszer a gyakorlatban nem csak az elöre eltervezett módon képes megváltoztatni a mérés tárgyát. A folyamatok irányítói olykor hajlamosak a mérőszámok rövid távon minél kedvezőbb elmozdulásához alakítani a döntéseiket, ami könnyen vezethet az erőforrások nem optimális felhasználásához, vagy a strukturális átalakítások elodázásához. Különösen igaz ez abban az esetben, ha az értékelésre használt mérőszámok nem teljeskörüen fedik le a mérni kívánt folyamatot (ilyenkor probléma lehet, hogy a beavatkozások tervezésénél nem kerül hangsúly a nem mért összetevőkre), komplex módszertanuk miatt nehezen átláthatók, vagy módszertanilag esetleg problémásak, így jelentősen torzíthatják az eredeti elképzeléseket, de akár a mérési szándékkal ellentétes hatást is kiválthatnak. A közigazgatás speciális sajátosságai, illetve átalakításának komplexitása, időigénye csak tovább nehezíti az ezen a területen zajló méréseket, illetve a mérések eredményeinek visszacsatolását a tervezésbe és a megvalósításba. Történik mindez egy olyan időszakban, amikor szemmel láthatóan felértékelődik a szerepe a különböző komplex mérőszámoknak a tervezés és a tudományos elemzés terén is (lásd például Makó - Illéssy - Mitchell, 2014, vagy Miszlivetz - Márkus, 2013).

Fontos tehát, hogy pontosan ismerjük az elektronikus közigazgatás értékelésére használatos méréseket, ezért tanulmányunk a jelenleg európai viszonylatban legszélesebb körben ismert és használt módszer, az Európai Unió másfél évtizedes múltra visszatekintő e-közigazgatási mérőrendszerét igyekszik kritikai módon ismertetni, az elérhető módszertani dokumentumok és a felmérések eredményeit ismertetö tanulmánykötetek (másod)elemzésével. Kitérünk továbbá a részben e felmérés eredményeiből képzett, a legújabb vonatkozó közösségi szakpolitika, a Digitális Menetrend előrehaladását mérni hivatott, 2015-ben létrehozott mérőszám, a DESI (Digital Economy and Society Index) közigazgatásra vonatkozó pillérének elemzésére, tágabb kontextust teremtve az eredmények értelmezéséhez, a mérőszámok felhasználásának megfe-

\footnotetext{
${ }^{5}$ https://publicadministration.un.org/egovkb/en-us/\#.Ws8zIX--1D8

${ }^{6}$ Noha a hazai szakmai közbeszédben a benchmarking kifejezés széles körben használatos, a tanulmányban ennek magyar megfelelőjeként az „összehasonlító felmérés" kifejezést használjuk a továbbiakban.

7 A mérőeszközöket sokszor explicit módon politikai célokhoz illesztik, így azok nem mindig az elektronikus közigazgatás általános vagy „ideális” állapotát, hanem az adott szakpolitikához leginkább kötődő dimenzióit értékelik. Az Európai Unió mérőrendszere például az eEurope Akcióterv nyomon követésének igényéből nőtt ki: https://ec.europa.eu/digital-single-market/en/news/egovernment-indicators-benchmarking-eeurope
} 
lelő módozataihoz. Tesszük ezt elsősorban azért, hogy elösegítsük az e-közigazgatási fejlesztések értékeléséről szóló, szélesebb körü hazai párbeszéd kialakulását.

\section{Háttér: az összehasonlító felmérések és elektronikus közigazgatás közös fejlődése és kihívásai}

Az e-közigazgatás nagyjából a '90-es évek közepe óta íródó történetét végigkövették a fejlesztések eredményeit célzó értékelések és mérések lebonyolítása is, melyek zömmel a kínálati-oldalra koncentráltak, azaz leginkább arra, hogy a különböző szolgáltatásoknak létezik-e internetes, online elérhetősége, és ha igen, az milyen ügyintézést tesz lehetővé. Ezek az értékelések általában kiterjedtek menynyiségi (a közigazgatási ügyek mekkora hányada érhető el elektronikus csatornákon) és bizonyos értelemben minőségi (milyen szintü ügyintézést tesz lehetővé az adott online megoldás) szempontokra is. Ez utóbbi ismérv kapcsán a 2000-es évek fordulóján megszületett a sokszor idézett, illetve számos más mérési rendszer által is használt, lineáris négyes modell, amely „érettség” szempontjából négy, egymásra épülőnek tekintett lépcsőt különített el az elektronikus ügyfélkiszolgálás szintjeit illetően:

1. szint: információk elérhetővé tétele,

2. szint: letölthető ürlapok elérhetősége,

3. szint: elektronikusan visszaküldhető ürlapok,

4. szint: teljes körü elektronikus ügyintézés.

A fenti beosztás első előfordulásával Codagnone et al. (2015) áttekintése alapján Ausztráliában találkozhatunk (ANAO, 1999). 2001-től szintén ez a négyes modell szolgált alapjául az Európai Bizottság által indított értékeléseknek is (Capgemini Ernst \& Young, 2001), amely 2007-ben bővült ki egy, a proaktivitást, a közigazgatás rendelkezésére álló adatok alapján személyre szabott szolgáltatások nyújtását jelentő ötödik szinttel. A különböző szinteken alapuló érettség (vagyis a különböző interakciós szintek) a tagállamok javaslati alapján összeállított 20 alapvető közszolgáltatás esetében került mérése (Európai Bizottság, 2001), melyek közül 12 állampolgári, 8 pedig vállalkozási ügyet jelentett. A vizsgált szolgáltatások és az érettségen alapuló modell - az ötödik szint bevezetésén túl gyakorlatilag változtatás nélkül - 2010-ig maradt használatban az Európai Unióban.

Mindezek mellett számos más mérési rendszer is kialakult, amelyek noha gyakran hasonlatosak voltak módszertanban, az eredményeik sokszor mégis jelentősen különböztek. Janssen és munkatársai (2004) átfogó kutatásuk során 18, az évezred elején használatban lévő e-közigazgatási (vagy a témakörhöz szorosan köthetö) értékelö rendszert ${ }^{8}$ elemezve megállapítják, hogy már a különböző mérések által használt fogalomrendszer is eltérő lehet, ami jelentösen befolyásolja az eredményeket, illetve azok interpretációját. Ez önmagában - és figyelembe véve a szerzők által választott forrásmunkák sokszínűségét - nem problémás, a gondot az okozhatja, ha eltérö fogalomrendszerü (és így fókuszú) értékelések eredményeit hasonlítják össze, esetleg az eredményeket a közigazgatás a mérésben nem érintett részeire is általános érvényűként kezelik. A szerzők szintén megállapítják, hogy a felmérések általában egy szükitett e-közigazgatás fogalommal dolgoznak, amely alapvetöen az online szolgáltatásnyújtást, illetve annak bizonyos dimenzióit jelenti. Ezzel összefüggésben a szerzők megállapítják, hogy az e-közigazgatás mérésére számos különböző indikátor használható, de az értékelések általában a kimenet (output, azaz leginkább kínálati oldali), vagy a környezeti (environment, például általános információs társadalom fejlettségi mutatók) típusúakat részesítik előnyben, míg a hatásokat (impact), vagy a ráfordításokat (input) értékelő mutatókból és vizsgálatokból jóval kevesebb tanulmányban találtak példát. Történik ez annak ellenére, hogy a teljes képhez a kínálati oldal ismeretén túl az igényeket, a felhasználók elégedettségét, de az adott ország tágabb „e-felkészültségét” is szükséges lenne (Janssen - Rotthier - Snijkers, 2004) ismerni.

A kínálati oldal túlsúlya azt is jelenti, hogy az így születő eredmények csak szűkebb aspektusát tárják fel a problémakörnek. Így például az ezekkel a módszerekkel készült vizsgálatok segítségével nem, vagy csak elenyésző mértékben lehet érdemi következtetéseket levonni a háttérrendszerek müködésére, a közigazgatás müködésének átalakítására. További probléma, hogy az ilyen felmérések nem reflektálnak a szolgáltatások valódi használatának elterjedtségére a társadalomban, illetve (különösen igaz ez a korábbi EU-s öszszehasonlító felmérés módszertanára, a 20 legfontosabbként kijelölt ügytípusra) a szolgáltatásokat monolitikus, egyedi struktúráknak kezeli, miközben a felhasználói igények horizontálisabbak, akár több szolgáltatáson átívelnek, egy adott életszituációban nem csak a mért egyetlen ügyre vonatkozhatnak (Codagnone et al., 2015). Számos kutatás mutatta ki, hogy a magas színvonalú kínálati oldal nem jelent automatikusan magas használati mutatókat, Fernández-i-Marín (2011) például az internethasználat (egy adott országban az internetet használók aránya) és az e-közigazgatás terjedésének vizsgálata során arra az eredményre jutott, hogy amíg az internet használata nem ér el bizonyos kritikus tömeget, addig az e-közigazgatás használata és a szolgáltatások elérhetősége között nincs statisztikailag kimutatható kapcsolat. Az internethasználat bizonyos szintjének elérése után azonban az e-közigazgatás célzott fejlesztésnek jelentős hatása lehet a használat terjedésére - ennek megfelelöen a fejlesztések és a befektetések idözitése is fontos sikertényezö lehet. Érdekes kérdéseket vet fel ugyanakkor, hogy mi lehet annak a jelenségnek a hátterében, ha az internethasználat meghaladja a kritikus tömeget ugyan a lakosság körében, de a komplexebb internetes alkalmazások (az e-közigazgatás magasabb szintjei mellett az olyan tranzakciós szolgáltatások, mint például az e-bank vagy az elektronikus kereske-

\footnotetext{
8 A vizsgált módszerek között szerepelt egyebek mellett az európai uniós benchmark jelentések 2003-as évi kiadása, az ENSZ 2002-es e-közigazgatási jelentése, a Bertelsmann Alapítvány szintén 2002-ben megjelent Balanced eGovernment jelentése, de néhány ország egyedi kiadványai (Írország, Ausztrália, Egyesült Királyság, Hollandia), illetve általánosan az információs társadalom érettségét mérő tanulmányok (mint például a Harvard University 2003-as „The networked readiness of nations” jelentése) is helyet kaptak az áttekintésben.
} 
delem) használata alacsony szinten látszik stabilizálódnimint ahogy Magyarország esetében az utóbbi évek adatai erre az állapotra engednek következtetni ${ }^{9}$. Ha Fernándezi-Marín logikáját kiterjesztjük, akkor a hazai interneten elérhető tranzakciós szolgáltatások minőségéről általában véve mondhatnánk, hogy alacsony, ami vélhetően csak részben igaz, sokkal inkább abba az irányba mutat, hogy adott szolgáltatások használatát az internetezés társadalmi elterjedtségén túl számos országspecifikus tényező is alakítja (aminek a részletes vizsgálata is egyéb, kvantitatív és kvalitatív módszer bevonásával lenne elvégezhetö).

Misuraca és munkatársai (2013) arra hívják fel a figyelmet, hogy a becnhmarking során elengedhetetlen egy olyan, önreflexív szempont beemelése, amely folyamatosan azt méri és értékeli, hogy mit mérünk és értékelünk. A sokat idézett, Solow-tól (1987) származó, azóta éppen a mérési módszerek fejlődésének köszönhetően részben többek által cáfolt IT-paradoxonhoz (,mindenhol ott vannak a számitógépek, kivéve a termelékenységi mutatókat") hasonló tapasztalható az e-közigazgatásban is: számos és kimerítő adattal rendelkezünk ezeknek a szolgáltatásoknak az elérhetőségéről és szofisztikáltsági szintjéről, miközben kevés a mérési adat és a bizonyíték a valódi hatások tekintetében (Misuraca - Codagnone - Rossel, 2013). Ezt részben indokolja, hogy a bonyolultabb mérések (egyszerre számos országban történő) megvalósításához szélesebb körü adatgyüjtés és komplex adatfeldolgozás szükséges, nem beszélve a puha, „soft" tényezők figyelembevétele esetén okozott módszertani komplikációkról. A hiányzó megközelitések és vizsgálatok komplexebb módszertani apparátust és a legtöbb esetben jóval nagyobb költségráforditást igényelnének, ami szintén sokkal inkább a kínálati oldal irányába tolják el az elemzések tárgyát a back-office folyamatok értékelése, valamint a felhasználói elégedettség ${ }^{10}$, megtérülés és a tényleges hatások felöl (Janssen - Rotthier - Snijkers, 2004). Szintén megemlítendők az egyes államok közigazgatásai közötti különbségek, melyek kiterjedésükben, funkcióik, hagyományaik és számos egyéb tényezö alapján korlátozottan összevethetök, és behatárolják azokat a területeket, ahol az összehasonlító elemzések valós eredményekkel járhatnak. (Ehhez járulhat még, ha az adatfelvétel nem egyetlen szervezet által, szabályozott módszertan alapján zajlik, hanem például elöre lefektetett módszertani keretek között a különböző országok hivatali saját méréseket végeznek.)

Szintén a mérés kereteinek meghatározásához ad adalékot Bannister (2007), aki áttekintve az összehasonlító vizsgálatok szerepét az elektronikus közigazgatás kontextusában arra a következtetésre jutott, hogy (legalábbis a tanulmányának megjelenésekor széles körben használt) összehasonlitó felmérések nem igazán alkalmasak a teljes körü, átfogó értékelésre, a fejlödés okainak és a hiányos- ságok részletes leírására. Azok leginkább egy általános kép megalkotására használhatók, ugyanakkor (vagy ennek ellenére) az összehasonlító felmérések komoly politikai, vagy akár gazdasági hatással lehetnek, ezért fontos az eredmények valós percepciója és interpretációja a döntéshozók számára, másrészt elengedhetetlenek a további fejlesztések a területen, a mérések folyamatos finomhangolása. Hasonló megállapításra jutott Kunstelj és Vintar (2004) az összehasonlító vizsgálatok hatását elemezve az e-közigazgatás fejlesztési irányaira, kitérve a részletek fontosságára és a szolgáltatások különbözőségére (például a kínálati oldali elemzés figyelmen kívül hagyhat akár teljesen elektronikus alapokon nyugvó, de a kormányzati portálon publikus interfésszel nem rendelkező ügytípusokat, vagy értékel olyanokat, mint a különböző igazolások kiállítása, amelyek nem jelentenek hozzáadott értéket a felhasználónak és inkább az automatizálásuk lenne kívánatos).

Az Európai Unió e-közigazgatási összehasonlító felmérésének módszertana alapvetően változatlan maradt 2001 és 2010 között, miközben a politikai és stratégiai célkitüzések időközben átalakultak, de a technológiai fejlődés sem elhanyagolható manapság az informatikában egy évtized alatt. Ennek hatására az időszak végére egyre problémásabbak lettek a felmérés eredményei, melynek a hazai recepciójára is találunk példát (Molnár, 2011). A kritikák egyrészt hangsúlyozták a felmérés valós célokat felülíró, a szabályozás felé mutató hatását, valamint a vizsgálat tárgyának (20 alapvető közszolgáltatás) elavultságát, leszükítő voltát, hiszen számos ország évekig maximális pontszámot ért el a felmérések eredményei alapján.

Codagnone és munkatársai (2015) álláspontja szerint az Európai Unió mérésének átalakításakor sokáig a tagállamok egy része (akik jól szerepeltek az értékelésben, illetve azok, akik specifikusan a mért tényezők, vagyis az online jelenlét irányába csoportosították át fejlesztési forrásaikat (néhol felhasználói felületet létrehozva ugyan, de a valós háttérfolyamatok és az igazi hatékonyság megteremtése nélkül)) ellenérdekelt volt a bevett metódus átalakításában, miközben a szakpolitikai háttér - aminek előrehaladását lett volna hivatott eredetileg mérni a metódus - többször változott. A hasonló mérőeszközök folyamatos fejlesztése és alakítása ugyanakkor elengedhetetlen azoknak a rendszereknek a fejlesztéséhez, amiknek a mérésére létrehozták őket (Rorissa - Demissie - Pardo, 2011), főleg ha a célok, az eszközök és a környezet időközben maguk is fejlődnek, átalakulnak. Codagnone és Undheim (2008) utal arra is, hogy a bevett és rendszeres összehasonlító felmérések, mint amilyen az Európai Unió e-közigazgatási értékelése, gyakorlatilag egy „kvázi-szabályozási”, funkciót is betöltenek, vagyis normatívvá válnak, ami látva a korábbiakban bemutatott hatásmechanizmusokat,

\footnotetext{
${ }^{9}$ https://ec.europa.eu/digital-single-market/en/scoreboard/hungary

${ }^{10}$ Érdekes kettősség, hogy mindeközben az elektronikus közigazgatás szakirodalmának jelentős részét teszik ki a felhasználó oldali felmérések, melyek különböző elfogadási modelleken alapulnak (ezek áttekintéséhez lásd például Keszey - Zsukk, 2017). Ezek a kutatási eredmények ugyanakkor általában széles körü összehasonlításra nem használhatók, mivel általában egy, vagy néhány országra és szolgáltatásra terjednek ki, és a legváltozatosabb módszertanokkal készülnek, rendszerint egy időpillanatban mért állapotot rögzítve.
} 
sok esetben akár a szakpolitikáról is elvonja a figyelmet. Előfordulhat, hogy a felmérések során kapott értékek növelése akár külön vezetői célként, saját kontextusában fogalmazódik meg, nem szervesen összekapcsolódva a stratégiai célokkal, esetleg „újrahangszereli” azok hangsúlyait - az épp aktuális mérési módszertan szempontjából.

A továbbiakban Magyarország példáján keresztül mutatjuk be a 2010 után az Európai Unióban használt, jelenleg is érvényben lévő eGovernment Benchmark módszertanát. Kitérünk azokra a pontokra, ahol az reflektált a korábban megfogalmazott kritikákra, végezetül pedig elemezzük, hogy részben az összehasonlító felmérés adataiból képzett új, európai szintű társadalmi és gazdasági hatásokat mérő index (DESI) e-közigazgatási mutatója mennyiben ragadja meg valójában az e-közigazgatás fejlődését, illetve megvizsgáljuk, hogy a különböző mutatók milyen mértékben és körülmények között használhatók érdemi visszajelzésként a döntéshozók számára.

\section{Az Európai Unió e-közigazgatási értékelési rendszerének változása és Magyarország adatai}

A 2010-es értékelés után az Európai Unió e-közigazgatást értékelö éves jelentéseit (eGovernment Benchmarking Report) egy új, az évtized elején lefektetett keretrendszer alapján készítették el (eGovernment Benchmark Framework 2012-2015). A megújított módszertan (Európai Bizottság, 2015a) már nemcsak bizonyos szolgáltatások meglétét vagy nem létét, illetve azok érettségi szintjét vizsgálta (és a 2016-ban lezajlott módszertani ráncfelvarrás után a 2020-ig tartó időszakban vizsgálni is fogja (Európai Bizottság, 2016a)), hanem egyrészt a próbavásárlások vagy próbaügyintézések módszerével (mystery shopping) kíván átfogóbb következtetéseket levonni. Másrészt a próbaügyintézések mellett egy, az eredeti elképzelés szerint nagymintás (a nagyobb országokban 10001000, a legkisebb lakosságszámú országokban 200-200, összesen uniós szinten 27000 fős) kérdöíves adatfelvételen keresztül a felhasználói oldal percepcióit, használati szokásait és elégedettségét is igyekezett beépíteni a felmérés folyamatába. Egy ilyen adatfelvételre az új módszertan első évében, 2012-ben sor került, ám a felmérést azóta sem ismételték meg, legalábbis semmilyen, publikus adatbázisban vagy jelentésben nem található ennek nyoma, bár jelen tanulmány szerzője semmilyen utalást nem talált a publikus módszertani dokumentumokban, hogy miért változott az eredetileg felvázolt koncepció. A mérőrendszert a 2011-2015 közötti időszakra vonatkozó e-Közigazgatási Akcióterv (Európai Bizottság, 2010) prioritásai mentén alakították ki, vagyis ismét igyekeztek a vizsgálatot a lehető legjobban a szakpolitika támogatásához hangolni. Ezek a prioritások a következők voltak:

- Felhasználó támogatása (User Empowerment),

- Digitális egységes piac (Digital Single Market),

- Hatékonyság és eredményesség (Efficiency and Effectiveness),

- Elöfeltételek (Pre-conditions).

A prioritások előrehaladását úgynevezett felső szintű értékelési területek (Top Level Benchmarks) segítségével térképezi fel az értékelési folyamat, melyekből eredetileg a módszertani dokumentumok szerint hatot definiáltak:

- A felhasználó-központú kormányzat (User-centric Government) mutató az e-szolgáltatások elérhetőségének és használhatóságának mérését célozta, mindezek mellett vizsgálta a felhasználói tudatosságot és a használat korlátait és akadályait a felhasználók körében. Ez a megközelítés reflektál a korábbi kritikákra és az online jelenléten kívül annak tágabb értelemben vett minőségét is vizsgálja, valamint (az említett nagymintás adatfelvétellel) a felhasználói oldal percepcióit is igyekezett (volna) feltárni.

- Az átlátható kormányzás (Transparent Government) értékelte a kormányzat szervezeti müködésének, folyamatainak és az általuk nyújtott szolgáltatások, valamint a személyes adatok kezelésének átláthatóságát.

- Az összekapcsolt kormányzat (Seamless Government) mutató az állampolgárok és a vállalkozások esetében fejezte ki bizonyos kiemelt, határokon átnyúló szolgáltatások elérhetőségét és használhatósági kritériumait.

- Az eredményes kormányzat (Effective Government) a felhasználó-oldali kérdésekre összpontosított, a tényleges használat, a felhasználói elégedettség és percepciók kérdéseire. Többek között arra kereste a választ, hogy az elektronikus utat preferálják-e a felhasználók, illetve hogy a kormányzatok elérik-e a felhasználói elégedettséggel kapcsolatos célkitüzéseiket.

- A hatékony kormányzat (Efficient Government) mutató értékelte a valós használatot és a papíralapú ügyintézésről elektronikusra történő váltás sikerességét.

- Az okos kormányzat (Smart Government) referencia kulcstényezők meglétét vizsgálta. A kulcstényezők olyan (elsősorban technikai) elöfeltételek, melyek szükségesek a hatékony e-közigazgatási szolgáltatások nyújtásához és igénybevételéhez.

A felsorolásból és a módszertani bővülésből látható, hogy az összehasonlító felmérés alaplogikája 2010 után - részben a kritikákra reflektálva, másrészt az új szakpolitikai célkitűzésekhez igazodva - megváltozott, illetve továbbfejlődött. Továbbra is hangsúlyos a kínálati oldali értékelése, de a mért szempontok száma megnőtt, és a kulcstényezők bevonásával a háttérfolyamatok átalakításának szintjéröl is megpróbál következtetéseket levonni a felmérés. A digitális egységes piac megteremtésének az e-közigazgatáson jóval túlmutató politikai célkitűzése pedig a határon átnyúló szolgáltatásnyújtás felmérésének igényét vonta be a vizsgálatba (előbb Seamless Government, később, mint ahogy azt látni fogjuk, Cross Border Mobility néven). A hat felső szintü értékelési szempont tematikájából látható, hogy különböző mértékben építettek volna a két főbb módszertani elemre, a próbaügyintézésekre és a nagymintás kérdőíves felmérésre. A tagállamok pontszámainak meghatározásakor az ügyfél- 
központú közigazgatás mutató esetében a módszertani dokumentum alapján az érték felét adta volna a nagymintás adatfelvétel eredményeiből képzett mutatók, míg a másik fele a próbaügyindítások különböző területeken történő értékeléseinek összesített értékeiből állt volna össze. Az eredményes kormányzat mutató értékei teljes egészében a kérdőíves vizsgálat eredményeiből származtak volna, az összes többi esetben a próbavásárlások eredményei szolgáltatták volna a Top Level Benchmarkok értékeit. Végül a kétévenkéntire tervezett kérdőíves felmérés (vélhetően egyrészt költségcsökkentési, másrészt pedig a módszertani egyszerüsítés okán) nem került be a rendszeres felmérés módszertanába, az egyetlen lekérdezés eredményei a 2012-es évi jelentésben (Európai Bizottság-CapGemini, 2013) szerepelnek (abban az évben még csonka próbaügyintézési eredményekkel, erről lásd a következő bekezdést), de már az eredeti módszertani dokumentumhoz képest más felső szintü értékelési területek (user centricity (ügyfélközpontúság), transparent government (átlátható kormányzat), cross border mobility (határon átnyúló szolgáltatások, állampolgár és vállalkozás alkategóriával) és key enablers (kulcstényezők)) szerint (illetve itt még szerepel a csak a kérdőíves felmérés eredményeiből képzett 'Effective Government', ami a későbbiekben már nem szerepel, mint értékelési terület).

A 20 alapvető szolgáltatást, mint a vizsgálat tárgyát, szintén leváltották, az elemzés alapjául az „élethelyzet” szolgál (például születés, beiskolázás, cégalapítás stb.), ezzel kívánva holisztikusabbá tenni a korábbi, monolit elemzési struktúrát, illetve a felhasználói szemléletet jobban érvényesíteni, hiszen a legtöbb esetben bizonyos ügyeket egy adott életszituációban együtt, akár szekvenciálisan kell elvégeznie az ügyfeleknek. Fontos tudnivaló, hogy nem minden élethelyzetet értékelnek minden évben: páros években és páratlan években más-más területek vizsgálata történik meg. 2016-ban a már említett módszertani felülvizsgálat során egy újabb élethelyzetet alakítottak ki, így 2016 és 2020 között minden évben 4-4 élethelyzet értékelése zajlik le (minden évben 3-3 állampolgári és 1-1 vállalkozásra vonatkozó élethelyzet). Ezt a ,vetésforgót” az adatfelmérés költségei mellett az is indokolja, hogy a területeken egy év alatt sokszor nem történik olyan mérhető változás, másrészt azonban azt is okozza, hogy az eredmények lassan, akár több év alatt épülnek be a pontszámokba. Ha például egy adott élethelyzethez sorolt szolgáltatás megújítására kerül sor a felmérés lezajlása után, de még az adott évben, az esetleges pozitív hatás a két és fél év múlva, rendszerint az év végén megjelenő publikációban szereplő pontszámokban lesz érzékelhető. Az 1. táblázatban foglaltuk össze az élethelyzetek tartalmát (a vállalkozásokra vonatkozó élethelyzeteket eltérő háttérszínnel jelöltük), illetve értékelésük ütemezését.

A korábbi módszertanhoz képest tehát egyrészt bővült az egy évben elemzett szolgáltatások száma, másrészt az értékelés a felmérés egy-egy évében kevesebb területet fog át, illetve néhol kiterjedhetnek olyan szolgáltatásokra (például a költözés esetében a közmüszolgáltatók, illetve az oktatás terén a felsőoktatási intézmények) is, amelyeket nem a központi közigazgatás nyújt (vagy az igazságszolgáltatás esetén teljesen más kontextusban zajlanak). A pontszámokat összesítve, egyfajta „gördülö” rendszerben frissítették annak érdekében, hogy a csökkentett körü éves adatfelvétel ellenére a lehetőségekhez képest teljes képet nyújtsanak, tehát az érdemi teljesítmény két év (egy teljes „ciklus”) átlagából adódik össze, míg egy adott élethelyzeten belül az elörehaladás elemzésére kétévenként van

\section{Páros évek (2012 és 2014, illetve 2016 és 2018) \\ Cégindítás (Starting business and early trading opera- tions): 33 szolgáltatás került besorolásra, a cégbejegyzés, az adó- és társadalombiztosítási ügyek mellett a kezdeti lé- pések közé tartozik például a munkavállalók felvétele és a környezetvédelmi engedélyezés.}

Tanulás (Studying): a 14 szolgáltatásból álló élethelyzet azt értékeli, hogy a felsőoktatással kapcsolatos ügyek (pl. karrier-tanácsadás, ösztöndíj-ügyintézés külföldi tanulmányok esetén) mennyire intézhetők az interneten (felvételi és oktatási szakaszban egyaránt).

Munkanélkülivé válás, munkakeresés (Losing and finding $\boldsymbol{a}$ job): a munkahely elvesztéséhez és a munkakereséshez kapcsolódó, összesen 22 szolgáltatás (pl. támogatások, képzési programok).

Családi ügvek (Familv life): a családalapításhoz, illetve gyermekvállaláshoz kapcsolódó ügyek (például házasság, gyermekszületés), 10 szolgáltatás, 2016-tól.
Páratlan évek (2013 és 2015, illetve 2017 és 2019)

Cég müködtetése (Regular business operations): összesen 11, a gazdálkodó egység mindennapi müködéséhez szükséges szolgáltatás (adózás, emberi erőforrások kezelése, áfavisszaigénylés).

Költözés (Moving): más városba, lakcímre költözés esetén a szükséges változások átvezettetése, egyéb közszolgáltatásokhoz történő bejelentések, összesen 6 ügy.

Személvgépjármüvel kapcsolatos ügvek (Owning and driving a car): az autóvásárláshoz kötődő ügyintézés, illetve az üzemben tartáshoz, vezetéshez kapcsolódó ügyek (bírságok, parkolási engedélyek, adók), összesen 12 szolgáltatás.

Kis értékü követelések eliárásának elindítása (Starting a small scale procedure): az információszerzéstöl és az ügyindítástól az ítéletig/fellebbezésig 7 ügy. 
lehetőség (a 2012-es és a 2016-os év ebből a szempontból rendhagyó, az ezekre az évekre vonatkozó adatok a többi évnél szükebb körben értelmezhetök). Fontos információ még, hogy tagállami konzultáció során az élethelyzeteket igyekeztek úgy kialakítani, hogy minden értékelt országban létező, és lehetőleg hasonló eljárások kerüljenek a felmérésbe. A tagállamok közigazgatásainak különbözőségei miatt ez természetesen nem sikerülhet teljesen, így bizonyos élethelyzet-elemeknél a próbavásárlóknak lehetőségük van jelölni a relevancia hiányát, így az adott részfolyamat nem számítódik bele az ország pontszámába.

A próbaügyintézések előkészítéséről és menetéröl is érdemes néhány fontosabb sarokpontot megemlíteni. Az adatfelvétel e részével kapcsolatban a legfontosabb jellemző, hogy országonként két értékelő, „,vásárló/ügyindító” végezte/végzi ezt a feladatot (a két elemzést egymással is összevetik az értékelés során, az esetleges inkonzisztenciák esetén annak okát feltárják). A próbavásárlók, akiknek rendelkezniük kell az általuk vizsgált ország elektronikus azonosítására használatos megoldásával (hazánk esetében például Ügyfélkapu vagy e-személyi) előzetes képzésben részesülnek, melynek fő célja a szubjektivitás minimalizálása és a minél egységesebb értékelői szemlélet kialakítása (a legelső, 2011-es értékelés során szándékosan szakértőket kértek fel, az új módszertan alapjait lefektetendö). A próbaügyindítások során egy elöre meghatározott, kötött struktúrájú, zömében eldöntendő, igen/nem kérdéseket tartalmazó „ellenőrzőlista” (checklist) alapján értékelik az adott élethelyzethez sorolt ügytípusokat, az ,ügyintézést”. Minden értékelő a saját hazájában végzi az értékelést (a nyelvi korlátok és a specifikus ismeretek miatt), a határon átnyúló szolgáltatások esetén pedig a két próbaügyintéző közül az egyiket véletlenül választják a többi ország próbaügyindítói közül, a másikat pedig ügyszámgyakoriság alapján, általában egy szomszédos országból jelölik ki. A próbaügyintézőknek adott időablak alatt (egy nap) kell elvégezniük egy élethelyzethez kapcsolódó értékelést. Ha egy adott ellenőrzendő elemet meghatározott idő alatt nem találnak meg az értékelők, akkor az értékelés negatív lesz, ami nem jelenti automatikusan azt, hogy a keresett funkció nem létezik, de nagy valószínűséggel nem elérhető, vagy egy átlagos felhasználó számára nem kellően intuitív a használata, és így rejtve maradhat. A próbaügyintézők ugyanakkor tényleges tranzakciót nem végezhetnek, ha ez a megkötés nem teszi lehetővé a teljes értékelést, az adott rubrikák üresen maradnak. Ez az utóbbi két tényező számos bizonytalanságot okozhat a lehetőség szerint objektív értékelés elérésében, melyet a felmérést bonyolító cég a tagállamokkal az eredményekröl történő konzultációval igyekszik feloldani, illetve kezelhetővé tenni (szintén a tagállammal történő konzultáció keretében véglegesítik azt a hivatkozáslistát, amelyet a próbaügyintézők megkapnak, vagyis nem önállóan kell megkeresniük az élethelyzethez tartozó ügyek elektronikus elérhetőségét). A felmérés különböző fázisaiban így több esetben is konzultáció történik az értékelt országokkal. Összességében tehát két értékelő tranzakció nélküli értékelése, a tagállamokkal történő validálás és adatpótlás, majd az eredmények szakértők általi ellenőrzése és meghatározott képletek és súlyok alapján történő összesítése után áll össze a tagállamok éves eredménye.

A mit és ki kérdése után joggal merül fel a „milyen szempontrendszer alapján?" kérdése is. A próbaügyintézés négy fó értékelési területe további alindikátorokra bomlik (a 2. táblázatban ezek láthatók, az európai és a magyar adatokkal, a táblázatban az előző teljes értékelési ciklus (2012-2015) módszertani felülvizsgálatának eredményeként megváltozott kategóriák is láthatók a jobb szélső oszlopban, a 2017 végén megjelent, 2016-os eredmények mellett), melyeket minden élethelyzet minden részfolyamatára pontoznak. Az összesített átlagok adják a végső értéket az adott értékelési dimenzióban, az élethelyzetenként összesített dimenziók átlaga pedig az ország adott évi pontszámát. Az ügyfélközpontúság összetevői az online elérhetőség, jelentése szerint $0 \%$ az érték, ha egy szolgáltatás egyáltalán nem érhető el az interneten, $50 \%$, ha csak információk érhetők el az ügymenetröl és 100\%, ha a teljes ügy elektronikusan elintézhetö. Az adott élethelyzetre kapott érték súlyozott, 80\%-ot tesznek ki belöle az alapvető (basic) szolgáltatások, elengedhetetlen ügytípusok és 20\%-ot a kiterjesztett (extended) szolgáltatások, melyek leginkább kényelmi szolgáltatásokként értelmezhetők, segítik az ügymenetet, de nem elengedhetetlenül szükségesek a megoldáshoz. A próbaügyintézők minden esetben egy adott élethelyzetre szabott leírás, azaz perszona mentén végzik a feladatot, mely szimulálni igyekszik egy valós élethelyzetet, és az ehhez kapcsolódó közigazgatási eljárásokat.

A használhatóság alapvetően a könnyü müködtethetőség jellemzőit, valamint az elérhető támogató funkciók meglétét, a visszajelzés (feed-back) lehetőségeit veszi számba, egy maximális értékhez viszonyítva. A területhez tartozik még a használat könnyüségének és sebességének értékelése, amelyeket egy 1-10-ig terjedő skálán határoznak meg és pontoznak (a módszertani dokumentum útmutatója szerint: 1 - negatív, 5 - semleges, 10 - pozitív), ez a két mutató alapvetően a felhasználói élményt és elégedettséget kívánja megragadni, a szubjektum lehető legalacsonyabb szinten tartása mellett, de kétségkívül ez a módszertan legkevésbé objektív, a próbaügyintézőknek legnagyobb szabadságot nyújtó eleme. A 2012-2015-ig tartó időszakban az adott élethelyzetre vonatkozó használhatóság értéke összeállításakor az általános használhatóság 50\%, míg a könnyüség és a sebesség 25-25 százalékkal kerül súlyozásra. A teljes ügyfélközpontúság mutató esetében az elérhetőség $66 \%$, a használhatóság $33 \%$ súllyal esett latba (a felmérés módszertani útmutatója részletesen közli a különböző mutatóknál alkalmazott összevonási és súlyozási müveleteket, ezekre a későbbiekben terjedelmi okokból nem térünk ki, de fontos kiemelni, hogy a módszertan e része átlátható és jól dokumentált). 2016-tól a használhatóság alkategóriáit összevonták, és egy újabb tényező, a mobileszközökön történő használat támogatása (mobile friendliness) került be a szempontok közé, melyet nem próbavásárlás útján, hanem egy nyílt forráskódú szoftver segítségével értékelnek. A szoftver különböző szempontok alapján (például egymáshoz túl közeli linkek, nem reszponzív felület és így a képernyőről 
„kilógó” szövegek) ellenőrzi a hivatkozáslistában szereplő weboldalakat.

$\mathrm{Az}$ átlátható kormányzat mutató három részterületre (szolgáltatásnyújtás, állami szervezetek és személyes adatok) terjed ki, mindhárom esetében az értékelések zömében eldöntendő (igen/nem) kérdések alapján születnek. A $100 \%$ valamennyi, a vizsgálatba emelt szempont pozitív elbírálását (praktikusan meglétét) jelenti. Ebben a dimenzióban az értékek átlaga kerül kiszámításra, további súlyozás nélkül. A 2016-tól életbe lépő változások ezt

\begin{tabular}{|c|c|c|c|c|c|c|}
\hline & $\begin{array}{l}\text { Az értékelö } \\
\text { rendszer mutatói }\end{array}$ & $\begin{array}{c}\text { Kétéves } \\
\text { átlagpontszám } \\
\text { az EU 28+ országaira } \\
2015 / 2016 \\
\end{array}$ & $\begin{array}{l}\text { Magyar } \\
\text { eredmények } \\
2013\end{array}$ & $\begin{array}{l}\text { Magyar } \\
\text { eredmények } \\
2015\end{array}$ & $\begin{array}{l}\text { Magyar } \\
\text { eredmények } \\
2016\end{array}$ & $\begin{array}{l}\text { Az értékelő rendszer } \\
\text { mutatói 2016-tól }\end{array}$ \\
\hline \multirow{5}{*}{$\begin{array}{l}\text { Ügyfélköz- } \\
\text { pontúság } \\
\text { (user } \\
\text { centricity) }\end{array}$} & Összpontszám & $77 / 80$ & 45 & 53 & 68 & \\
\hline & $\begin{array}{l}\text { Online elérhetőség } \\
\text { (online availability) }\end{array}$ & $80 / 82$ & 45 & 55 & 75 & $\begin{array}{l}\text { Online elérhetőség } \\
\text { (online availability) }\end{array}$ \\
\hline & $\begin{array}{l}\text { Használhatóság } \\
\text { (usability) }\end{array}$ & $83 / 89$ & 43 & 49 & 64 & $\begin{array}{l}\text { Használhatóság } \\
\text { (usability) }\end{array}$ \\
\hline & \begin{tabular}{|l} 
Használat \\
könnyűsége \\
(ease of use)
\end{tabular} & $60 / 54$ & 51 & 48 & 31 & $\begin{array}{l}\text { Reszponzivitás } \\
\text { (mobile friendliness) }\end{array}$ \\
\hline & $\begin{array}{l}\text { Használat sebessége } \\
\text { (speed of use) }\end{array}$ & $57 /-$ & 55 & 54 & - & - \\
\hline \multirow{4}{*}{$\begin{array}{l}\text { Átlátható } \\
\text { kormányzat } \\
\text { (transparent } \\
\text { government) }\end{array}$} & Összpontszám & $55 / 59$ & 23 & 27 & 26 & \\
\hline & $\begin{array}{l}\text { Szolgáltatásnyújtás } \\
\text { (service delivery) }\end{array}$ & $47 / 50$ & 26 & 30 & 29 & $\begin{array}{l}\text { Szolgáltatásnyújtás } \\
\text { (service delivery) }\end{array}$ \\
\hline & $\begin{array}{l}\text { Állami szervezetek } \\
\text { (public organisations) }\end{array}$ & $64 / 73$ & 34 & 42 & 35 & $\begin{array}{l}\text { Állami szervezetek } \\
\text { (public organisations) }\end{array}$ \\
\hline & $\begin{array}{l}\text { Személyes adatok } \\
\text { (personal data) }\end{array}$ & $55 / 53$ & 10 & 10 & 15 & $\begin{array}{l}\text { Személyes adatok } \\
\text { (personal data) }\end{array}$ \\
\hline \multirow{5}{*}{$\begin{array}{l}\text { Határon } \\
\text { átivelö } \\
\text { mobilitás } \\
\text { (cross border } \\
\text { mobility) }\end{array}$} & Összpontszám & $55 /(61 / 65)$ & 17 & 24 & $40 / 30$ & $\begin{array}{l}\text { (Állampolgár/ } \\
\text { vállalkozás) }\end{array}$ \\
\hline & $\begin{array}{l}\text { Online elérhetőség } \\
\text { (online availability) }\end{array}$ & $56 /(74 / 73)$ & 15 & 25 & $56 / 59$ & $\begin{array}{l}\text { Online elérhetőség } \\
\text { (online availability) }\end{array}$ \\
\hline & $\begin{array}{l}\text { Használhatóság } \\
\text { (usability) }\end{array}$ & $63 /(76 / 79)$ & 22 & 22 & $33 / 0$ & $\begin{array}{l}\text { Használhatóság } \\
\text { (usability) }\end{array}$ \\
\hline & $\begin{array}{l}\text { Használat } \\
\text { könnyüsége } \\
\text { (ease of use) }\end{array}$ & 45/(14/29) & 21 & 23 & $0 / 0$ & $\begin{array}{l}\text { eID határon átívelö } \\
\text { használhatósága } \\
\text { (eID cross border) }\end{array}$ \\
\hline & $\begin{array}{l}\text { Használat } \\
\text { sebessége } \\
\text { (speed of use) }\end{array}$ & $41 /(24 / 43)$ & 21 & 22 & $33 / 0$ & $\begin{array}{l}\text { eDokumentumok } \\
\text { határon átivelö } \\
\text { használata (eDocu- } \\
\text { ments cross border) }\end{array}$ \\
\hline \multirow{6}{*}{$\begin{array}{l}\text { Kulcstényezők } \\
\text { (key enablers) }\end{array}$} & Összpontszám & $54 / 52$ & 30 & 20 & 33 & \\
\hline & $\begin{array}{l}\text { Elektronikus } \\
\text { azonosítás (eID) }\end{array}$ & $61 / 52$ & 38 & 49 & 43 & $\begin{array}{l}\text { Elektornikus } \\
\text { azonosítás (eID) }\end{array}$ \\
\hline & $\begin{array}{l}\text { eDokumentumok } \\
\text { (eDocuments) }\end{array}$ & $61 / 61$ & 78 & 60 & 60 & $\begin{array}{l}\text { eDokumentumok } \\
\text { (eDocuments) }\end{array}$ \\
\hline & $\begin{array}{l}\text { Eredeti adatforrások } \\
\text { (authentic sources) }\end{array}$ & $49 / 47$ & 52 & 19 & 17 & $\begin{array}{l}\text { Eredeti adatforrások } \\
\text { (authentic sources) }\end{array}$ \\
\hline & eSafe & $43 / 50$ & $\mathrm{n} / \mathrm{a}$ & $n / a$ & 13 & $\begin{array}{l}\text { Digitális posta } \\
\text { (digital post) }\end{array}$ \\
\hline & $\begin{array}{l}\text { Egykapus } \\
\text { bejelentkezés (Single } \\
\text { Sign On, SSO) }\end{array}$ & 63 & 43 & 14 & - & - \\
\hline
\end{tabular}

2. táblázat Magyarország és az Európai Unió átlaga a 2013-as, a 2015-ös (az előző értékelési időszak két teljes élethelyzeti ciklusának) és a 2016-os felmérés (négy élethelyzet elemzésén alapuló) eredményei (Európai Bizottság, 2016b, 2017a). Kiemelten (szürkével) jelölve a DESI indexhez felhasznált indikátorok, illetve dőlt betűvel jobb oldalon a módszertan változástatások során átalakított értékelési területek. 
a dimenziót érintették a legkevésbé, egy új kérdés került be arra vonatkozóan, hogy az ügyet intéző kap-e visszajelzést arról, hogy ki, mikor és miért fért hozzá a személyes adataihoz. A határon átnyúló szolgáltatások esetében eredetileg ugyanazok a szempontok képezték az értékelés alapját, mint a felhasználó-központú kormányzás esetében (az eredmények interpretálása markánsan szétválasztja az állampolgárok és a vállalkozások élethelyzeteit). A módszertani felülvizsgálat során ez a terület is átalakult: részben továbbra is az online elérhetőség korábban is vizsgált összetevői adják a dimenzió pontszámát, másrészt azonban két alapvető kulcstényezőt határon átnyúló viszonylatban is vizsgálnak (elektronikus azonosítás és e-dokumentumok). Az utolsó dimenzió a kulcstényezőké, amelyek az elektronikus ügyintézés egyfajta előfeltételeiként, horizontális tényezőiként foghatók fel, és jól láthatóan törekszik a korábbi összehasonlító felmérés azon hiányosságának kiküszöbölésére, amely a háttérrendszerek integráltságának fejlettségi szintjére vonatkozott (bár mint azt az irodalmi áttekintésben láttuk, esetenként kétségeink merülhetnek fel e rendszerek és megoldások kínálati oldali elemzésével kapcsolatban, különösen a próbavásárlás módszertanának ismeretében). Egyfajta esszenciáját próbálja nyújtani azoknak az összetevőknek, amelyek jelenléte elengedhetetlen a hatékony e-közigazgatási szolgáltatások igénybevételéhez (elektronikus azonosítás, elektronikus dokumentumok használhatósága, felhasznále az adott elektronikus ügymenet automatikusan olyan adatokat, amelyek már valamilyen állami nyilvántartásban szerepelnek a felhasználóról). A módszertani felülvizsgálat során ez a terület is átalakult, két kulcstényezőt (eSafe, SSO) kivezettek, helyettük a digitális postát (digital post) definiálták, mely azt mutatja, hogy rendelkezésre áll-e a felhasználók számára olyan digitális tárhely- vagy hasonló szolgáltatás, amelynek használatával teljes egészében kiválthatók a papíralapú dokumentumok.

\section{A módszertani változások és az összehasonlító felmérés értékelése}

A módszertan kialakításából számos következtetést levonhatunk. Az egyértelmü, hogy a 2001-2010 között használt eljáráshoz képest (számos, az irodalmi áttekintésben is bemutatott problémára reflektálva) kibővült az értékelés által lefedett tényezők köre. Az eredetileg betervezett és 2012-ben elvégzett nagymintás adatfelvételt a későbbiekben kivezették (és ezt a módszertani változást a Bizottság és a későbbi tanulmány(ok) készítői finoman szólva sem verték nagydobra), vagyis az eredetileg szélesebb körüre tervezett módszertan az első kétéves ciklus után ismét föként kinálati oldali kutatásként, négy felső szintű területet megtartva folytatódott tovább, és ez az új e-közigazgatási akcióterv bevezetésével sem változott. A 2016-ban kiadott módszertani dokumentum hangsúlyozza ugyan az összehasonlító felmérés az új, 2016-2019-ig szóló akciótervéhez igazítását, de az átvezetett, és döntö többségében a 2. táblázatban is látható változások leginkább módszertani finomhangolást jelentettek, amely a két teljes értékelési ciklus tapasztalatai (egy új élethelyzet bevezetése, kérdések pontosítása, néhány esetben bővítése) és a technológiai környezet változása (mobileszközökön való elérhetőség vizsgálata) indokolt.

Általánosságban elmondható, hogy jelentős mennyiségű összevonáson és súlyozáson esnek át a nyers, értékelésből származó adatok, mielőtt elnyerik végső formájukat, így az ilyen indexekkel kapcsolatos módszertani megállapítások szerint is jelentős mértékü információvesztés történik, azaz csak a végeredmény, a „legvégső” számérték vizsgálata során bizonyos tényezök elfedésre kerülhetnek. Ez nem jelenti azt, hogy az összesített mutató pontatlan, az ismertetett módszertannal készített felmérés alapján kialakított rangsorok alapvetően reális képet adnak, viszont az eredmények ,rendeltetésszerü”, a fejlesztések vagy a fejlesztési prioritások kialakitásánál történö felhasználásánál az indikátorrendszer teljes ismerete szükséges a döntéshozók részéröl. Ez ugyanakkor nem könnyü: a módszertan megértéséhez legszükségesebb információk ismertetése már jelen tanulmányban is túlburjánzónak tünhet, miközben az eredmények értő használatához az itt bemutatottnál mélyebb ismeretek szükségesek. Az ugyanakkor örvendetes, hogy a kutatás teljes adatbázisát nyilvánosságra hozzák, azaz minden élethelyzet minden ügyének értékelése visszakereshető a checklist kérdései alapján (Bannister (2007) korábban említett elemzése utalt rá, hogy a 2000-es évek elején közel sem volt ennyire áttekinthető a benchmark módszertani).

Noha örvendetes módon növekedett az értékelt szolgáltatások száma, az élethelyzetek rotációja miatt egy-egy év adott pontszámai már eleve egy szükebb portfólióról nyújtanak értékelést, miközben továbbra is maradhatnak olyan (akár egy adott ország közigazgatására speciálisan jellemző területek), amelyek nem fedtek le a vizsgálat során. Mindezek mellett érdemes arra is kitérni, hogy ezek a mérések sokszor önmagukban kezelik az elektronikus közigazgatást, annak megjelenési formája azonban számtalan módon történhet, akár a kínálati oldalon is. Példa lehet erre a magyar személyi jövedelemadó bevallásának új rendszere, és az ahhoz fejlesztett eSZJA felülete. Ha normatívan az online ügyintézést tekintjük elsődleges célnak, akkor a felhasználói elégedettség megteremtésének bizonyos lehetőségeiröl gyakorlatilag lemondunk. Az új SZJA-bevallás során például az adóhatóság által a meglévő elektronikus adatbázisokból proaktív módon (tehát egy fejlett háttérrendszer által) generált bevallás-tervezeteket számos csatornán, nem csak az online felületen (eSZJA) lehetett megtekinteni, hanem SMS-ben vagy kézzel írva papíron igényelni annak másolatát, amelyeket elfogadás után nem is kellett visszaküldeni (Csótó, 2017), tehát bizonyos értelemben érdemi papíralapú ügyintézés nem történik, de a hagyományos, „,benchmark"-i értelemben véve elektronikus sem, viszont számos olyan hibrid forma létezik, ami mindkét ügyintézési csatornát használja (ennek extrém példája, hogy elvileg az online felületről is lehet igényelni papíralapú bevallástervezetet). Felvetődik a kérdés, hogy egy digitális alapokon nyújtott, de a jelenlegi indikátorokkal nem minden ügyfél számára elektronikus úton tekinthető, mégis ügyfélbarát ügyintézési forma milyen pontszámokat érdemelne - ha az éves személyi jövedelemadó egyáltalán szerepelne az élethelyzetek valamelyikében. 
A felmérés ugyanakkor ismeri az ,automatizált” szolgáltatás fogalmát, mint magas színvonalú szolgáltatásét, de bizonyos értelemben a mostani magyar megoldást nem tekinthetjük teljesen annak. Ezért is tünik rossz iránynak a felhasználó-oldali felmérések elhanyagolása, amelyekből képet lehetne kapni a szolgáltatás érzékelt színvonaláról, megítéléséről.

Európai viszonylatú összehasonlító felmérések esetében felmerül a különböző szintű prioritások (nemzetiközösségi) megítélése is, vagy a szűkös források esetén időben elcsúszó fejlesztések is problémát jelenthetnek. A tagállamok eltérő fejlettsége is a helyzetet bonyolító tényezők, melyek kezelhetők ugyan a módszertan folyamatos finomhangolásával, ami viszont (a fejlettebb országok már említett lobbierejét is figyelembe véve) konzerválhatja az országok rangsorát egy meghatározott fejlődési pálya mentén, miközben a változó módszertan miatt az idősoros összehasonlítás, a valódi fejlődés mérése is nehézkesebbé válik. Nem szabad tehát szem elöl téveszteni, hogy ezek a mérőrendszerek ideális esetben milyen szakpolitika vagy akcióterv, esetünkben a vonatkozó európai uniós törekvések (E-közigazgatási Akcióterv 2016-2019, Digitális Menetrend, Egységes Digitális Piac megteremtése) tükröződnek, nem pedig egy egyetemes, ideáltipikus e-közigazgatási kép ${ }^{11}$, amelyet különböző módszertani szempontok (beleértve akár az évenkénti vizsgálat költségvonzatát is) alakítanak. Adott esetben a tagállamok ezekhez a szakpolitikákhoz hangolt fejlesztési terveik is tartalmazhatnak eltérő hangsúlyokat.

A számos országot átfogó, évente más élethelyzeteket vizsgáló értékelési rendszerben az idö is fontos tényezö az adatok értékelése során. Elképzelhető, hogy egy élethelyzetet érintő ügytípus értékelésekor egy nem sokkal korábban elvégzett fejlesztés már rögtön növeli az eredményeket, míg más, az adott évben kimaradó élethelyzetek esetében a következő értékelésig várni kell, így akár az adatok feldolgozását és publikálását is figyelembe véve akár két évig is elhúzódhat, mire egy, az eredményeket előmozdító változtatás a pontszámokban is tetten érhető lesz. A 2016-ra vonatkozó adatok például 2017 év végén láttak napvilágot, tehát az abban nem szereplő négy élethelyzetből kalkulált pontszámok legutóbb a 2015-ös év értékeléséből állnak rendelkezésre, várhatóan egészen 2018 végégig, amikor a 2017-ben lezajlott értékelés adatai publikussá válnak. A magas szintü összevont pontszámok ugyanakkor - ahogy azt a 2017-es tanulmány hangsúlyozza, a korábban ismertetett módszertani változtatásoknak köszönhetően - a 2016-os eredményektöl kezdve nem minden tekintetben összevethetök az elözö idöszak adataival (Európai Bizottság, 2017). Ez nem könnyíti meg az adatok értelmezését és könnyü interpretációját, illetve korlátozza az adatok hosszabb távon történő idő- soros használatát. A módszertan ismertetése után hazánk eredményein keresztül igyekszünk bemutatni az értékelörendszer müködését.

\section{Magyarország részletes eredményei az Európai Unió e-közigazgatási összehasonlitó felmérésében}

A 2. táblázatban egyrészt a legutóbbi, 2017 végén megjelent, 2016-os adatok szerepelnek, másrészt pedig az előző módszertannal készülve az utolsó két olyan év, amelyekben alapján a teljes élethelyzetciklus és közös módszertan szerint összehasonlítható a fejlődés (vagyis 2013 és 2015), a táblázatot a szélesebb körü összehasonlítást elősegítendő, a 2015-ös és a 2016-os év uniós átlagával egészítettük ki (Európai Bizottság, 2016b, 2017). Az adatok azt mutatják, hogy mind a négy felső szintü értékelésben jelenősen elmarad hazánk az uniós átlagtól. Természetesen a legmagasabb pontszámok ${ }^{12}$ a felhasználó-központúság témakörén belül a korábbi fö prioritás, az online elérhetőség terén mérhetők a tagállamokban $(80$ százalék), viszont beszédes, hogy az újabban az értékelésbe illesztett, a szolgáltatások minőségét és gördülékenységét jobban mérő mutatóknál (a használat könnyüsége és sebessége) már alacsonyabbak az értékek (60 és 57 százalék). Ez részben egy természetes folyamat: a szolgáltatások elektronikus elérhetősége után azok minél jobb használhatósága, a felhasználói igények minél magasabb szintü kielégítése racionálisan is a következő lépcsőfokot jelenti, amely mint láttuk, a stratégiai dokumentumokban is kiemelt szerepet kapott. A fejlettebb tagállam esetében pedig ezek az újabb kategóriák lehetővé teszik a teljesebb kép kialakítását, a differenciálást azon közigazgatások között, amelyek az elérhetőségben akár a maximumot, vagy ahhoz közeli értékeket értek el. Az eredményekre tekinthetünk ugyanakkor úgy is a szakirodalom alapján, hogy ha a fö hangsúly az online elérhetőségen van, akkor nem biztos, hogy az ahhoz kapcsolódó egyéb tényezők párhuzamos fejlesztése is hasonlóan hangsúlyos, így azoknak aztán fel kell zárkózniuk. Az is igaz ugyanakkor, hogy a felhasználói élmény erösítése önmagában is jóval nehezebb, mint az ,egyszeri” elérhetővé tétel az e-szolgáltatások esetében, illetve lassabban is haladhat. A mobileszközök beemelése a környezet folyamatos változására, az igények átalakulására hívják fel a figyelmet. Elmondható, hogy az eredmények, az értékelési rendszer, a szolgáltatások valódi minősége, a fejlesztési hangsúlyok és a technológiai környezet folyamatos kölcsönhatásban vannak. A 2016-os magyar eredményekben felzárkózás tapasztalható az uniós átlagokhoz képest az elérhetőség és a használhatóság alapvető mutatóiban, ugyanakkor az új, mobil mutatóban jelentős a lemaradásunk.

A transzparencia szempontjából az európai átlagok épphogy belecsúsznak az elfogadható kategóriába (illetve

\footnotetext{
${ }^{11}$ Tény ugyanakkor, hogy a jól működő elektronikus közigazgatás víziója nem sokat változott az elmúlt évtizedben, és ennek alapfunkciói tükröződnek a felmérés módszertanán is.

${ }^{12}$ A benchmark értékelése szerint 0-25 százalék között elégtelen (insufficient) egy ország teljesítménye, 25-50 százalék között mérsékelt (moderate), 50-75 százalék között elfogadható (fair) és 75 százalék fölött jó (good) egy-egy érték (minden elemzési terület pontszáma normalizált, 0-100 közötti értékre).
} 
a szolgáltatásnyújtásban el is maradnak attól). A magyar adatok még ezekhez a nem túl magas értékekhez képest is kifejezetten rosszak, különösen a személyes adatok kezelésének átláthatósága szempontjából, ahol a számok alapján két év alatt nem is történt érdemi elörelépés, és a négy élethelyzet alapján számolt 2016-os értékek sem mutatnak áttörést. A határon átívelő szolgáltatások bizonyos tekintetben a legrosszabb hazai eredményeket mutatják, az elérhetôség javulása a külföldiek számára nyújtott értékekben is visszatükröződik, de a kulcstényezők döntő többségét látva leginkább azt mondhatjuk, hogy a más tagállamokban élők számára a magyar közszolgáltatások „megközelíthetősége” minden tekintetben az elvárt minimum alatt marad.

A legvegyesebb - és az előzőnél bizonyos összetevőkben az európai összehasonlításban némileg talán kedvezőbb képet - a kulcstényezők köre mutatja, ahol az eDokumentumok elterjedtsége az uniós áltag szintjén áll, és az elektronikus azonosítás témájában sem jelentős az elmaradás (mely mutató módszertana szintén megváltozott, a felmérésbe újabb kérdés került, részben ez indokolja az értékek csökkenését 2015-höz képest), ugyanakkor az interoperabilitás szintjét mérö eredeti adatforrások, vagy az újonnan bevezetett digitális posta mutató jelentős elmaradást mutat. Megdöbbentő visszaesés látható ugyanakkor az eredeti adatforrások mutatóban, amely az első mérések adatai alapján magasan meghaladta az uniós átlagot is. Az első év értékelése során tehát valamilyen értelmezési, módszertani vagy adatrögzítési probléma történt, hiszen az e-közigazgatás kulcstényezői esetében nehéz elképzelni azt, hogy ezek a megoldások egyik évről a másikra gyakorlatilag eltünnek. Az élethelyzetek részletes eredményeinek vizsgálata közelebb vihet minket ennek az anomáliának a feltáráshoz (3. táblázat), mely egyben jól mutatja azt is, hogyan állnak össze egy ország pontszámai. A táblázatban szürkével jelöltük a visszaesés jól beazonosítható okát, mely a munkaügyek élethelyzetben keresendő. Az adatokat részletesen megvizsgálva azt látjuk, hogy az első évben az eredeti adatforrások mutató maximális értéket (100) kapott, míg ugyanez a mutató (az értékelt weboldalak változatlansága mellett) 2014-ben a minimális (0) pontszámot rögzítették. Vélhetően egy alapvető értelmezésbeli különbség áll a jelenség hátterében, amelyet a későbbiekben nem egységesítettek visszamenőleg, elképzelhető például, hogy automatizáltként tekintettek az élethelyzethez kapcsolódó tranzakciókra, de később már ez az értelmezés megváltozott. A két, markánsan eltérő érték ugyanakkor jelentős hatást gyakorolt a teljes pontszámra, mivel páros évek lévén ekkor még mindössze három élethelyzet adta az értékelés alapját. A tanulás élethelyzet is ellentmondásos eredményeket mutat, mivel egyik kulcstényezöhöz sem találunk rögzített pontszámot az első évek adattáblájában, összességében mégis szerepel a historikus adatok között egy 50-es érték ennél az értékelési szempontnál, ami két év múlva (hasonlóan a munkaügyekhez) szintén nullára módosult. Ez egyrészt arra hívja fel a figyelmet, hogy az összevont pontszámok értékelésénél számos szempontot kell figyelembe vennünk, másrészt pedig

\begin{tabular}{|c|c|c|c|c|c|c|c|c|c|c|c|c|}
\hline & \multicolumn{3}{|c|}{ Felhasználó-központúság } & \multicolumn{3}{|c|}{ Átláthatóság } & \multicolumn{3}{|c|}{ Határon átnyúló mobilitás } & \multicolumn{3}{|c|}{ Kulcstényezők } \\
\hline & $\begin{array}{l}\text { HU } \\
2012- \\
2013\end{array}$ & $\begin{array}{l}\text { HU } \\
2014- \\
2015\end{array}$ & $\begin{array}{l}\mathrm{HU} \\
2016\end{array}$ & $\begin{array}{l}\text { HU } \\
2012- \\
2013\end{array}$ & $\begin{array}{l}\text { HU } \\
2014- \\
2015\end{array}$ & $\begin{array}{l}\mathrm{HU} \\
2016\end{array}$ & $\begin{array}{c}\text { HU } \\
2012- \\
2013\end{array}$ & $\begin{array}{l}\text { HU } \\
2014- \\
2015\end{array}$ & $\begin{array}{l}\mathrm{HU} \\
2016\end{array}$ & $\begin{array}{l}\text { HU } \\
2012- \\
2013\end{array}$ & $\begin{array}{l}\mathrm{HU} \\
2014- \\
2015\end{array}$ & $\begin{array}{l}\mathrm{HU} \\
2016\end{array}$ \\
\hline $\begin{array}{l}\text { Vállalkozás } \\
\text { indítása } \\
\text { (páros évek) }\end{array}$ & 51 & 66 & 68 & 30 & 33 & 42 & 9 & 29 & 30 & 27 & 24 & 53 \\
\hline $\begin{array}{l}\text { Munkaügyek } \\
\text { (páros évek) }\end{array}$ & 63 & 58 & 65 & 30 & 33 & 37 & n.a. & n.a. & n.a. & 67 & 25 & 42 \\
\hline $\begin{array}{l}\text { Tanulás } \\
\text { (páros évek) }\end{array}$ & 51 & 55 & 77 & 15 & 18 & 19 & 38 & 56 & 40 & 50 & n.a. & 4 \\
\hline $\begin{array}{l}\text { Családi élet } \\
\text { (páros évek, } \\
\text { 2016-tól) }\end{array}$ & n.a. & n.a. & 61 & n.a. & n.a. & 6 & n.a. & n.a. & n.a. & n.a. & n.a. & 33 \\
\hline $\begin{array}{l}\text { Cég } \\
\text { múködtetése } \\
\text { (páratlan évek) }\end{array}$ & 63 & 71 & n.a. & 48 & 51 & n.a. & 45 & 47 & n.a. & 34 & 38 & n.a. \\
\hline $\begin{array}{l}\text { Költözés } \\
\text { (páratlan évek) }\end{array}$ & 41 & 60 & n.a. & 21 & 33 & n.a. & 8 & 8 & n.a. & 33 & 39 & n.a. \\
\hline $\begin{array}{l}\text { Gépjármü- } \\
\text { ügyintézés } \\
\text { (páratlan évek) }\end{array}$ & 29 & 49 & n.a. & 10 & 11 & n.a. & 2 & 2 & n.a. & 0 & 13 & n.a. \\
\hline $\begin{array}{l}\text { Bíróság } \\
\text { (páratlan évek) }\end{array}$ & 20 & 21 & n.a. & 10 & 12 & n.a. & 2 & 2 & n.a. & 0 & 0 & n.a. \\
\hline
\end{tabular}

3. táblázat Élethelyzet szerinti részletes adatok Magyarország és az EU 28 viszonylatában

(Európai Bizottság, 2016b, 2017) 
egy hasonlóan komplex módszertan elindítása vélhetően számos nehézséggel, döntési ponttal és dilemmával jár, amelyeket nem minden esetben sikerül rögtön megnyugtatóan rendezni.

A táblázatban elég egyértelműen látszik az is, hogy a páratlan években pontozott élethelyzetekben, különösen az igazságügy területén találkozunk messze átlag alatti értékekkel, amelyek az összesített értékeket jelentősen befolyásolhatják. A másik ilyen fontos, a hazai eredményekre vonatkozó, korábban az aggregált adatoknál is említett megállapítás, hogy az üzleti és tanulási célú ügyek kivételével a határon átnyúló szolgáltatások gyakorlatilag elérhetetlenek. Ez azért is problémás, mert az egységes közös piac kialakítására vonatkozó törekvések jegyében ez a témakör valószínűleg a jelenleginél is fontosabb lehet, és ez tükröződhet a módszertan legközelebbi megújítása során is. Ha pozitívumokat keresünk, akkor mindenképpen meg kell említeni, hogy a cégeknek nyújtott, határon átnyúló szolgáltatások esetében viszont jelentős emelkedést láthattunk 2013 és 2015 között, amelynek hátterében vélhetően a Szolgáltatási Irányelv (Európai Parlament és Tanács, 2006) elöírásainak történő megfelelés érdekében elindult magyar EUGO oldal ${ }^{13}$ lehet, ahol angol nyelven, összesítve, egyablakos módon váltak elérhetővé a cégindítással kapcsolatos információk angol nyelven. Ez utóbbi pontszámnövekedés mögött természetesen más tényezők is megbújhatnak, mégis jól jól mutatja a kapott értékek ilyen részletezettsége (ami már szintén összevonások eredménye), hogy noha az összesített eredmények nagy vonalakban képesek az országok közötti különbségek felvázolására, a valódi (legyenek azok akár szakpolitikai üzenettel bírók, vagy módszertani anomáliákra rávilágító) információk a részletekben bújnak meg.

Összességében elmondhatjuk, hogy az új európai uniós e-közigazgatási összehasonlító felmérés sok tekintetben reagált a korábbi módszertant ért kritikákra, még ha nem is küszöbölt ki minden, problematikusként azonosítható gyakorlatot. Általánosságban az adott élethelyzetekre vonatkoztatva és a kulcstényezőket tekintve alkalmas visszajelzést nyújtani a döntéshozóknak a legnagyobb hiányosságok azonosításában. Mivel a módszer az e-közigazgatás értékelésére szolgál, annak fejlettségét és potenciálját méri az EU-s politikai elképzelések kontextusában, megvannak a maga korlátai, ugyanakkor a jóval átfogóbb megközelítés miatt széles körű információforrásként szolgálhat, különösen a nyers adatok, és a kevésbé az összesített értékek szintjén: amint azt a 2. és 3. táblázatból láthattuk, ezek az összesítések jelentős információvesztéssel járnak, nem azonosíthatóak a fejlesztendő területek, élethelyzetekhez kapcsolódó ügyintézési lehetőségek és szolgáltatások.
Az Európai Bizottság (2016a) 2016 során kiadott módszertani felülvizsgálati dokumentuma alapján az itt ismertetett rendszer marad érvényben az új e-kormányzati akcióterv időszakában is, a 2016-19 közötti időszakban (így a 2020-ban publikálandó adatok még egész biztosan a jelen módszertan alapján lesznek felvéve).

\section{A digitális gazdaság és társadalom index (DESI) - a valós visszacsatolás vagy a hírverés eszköze?}

Jelen írás zárásaként érdemes kitérni a digitális gazdaság és társadalom fejlettségét mérő, 2015 óta megjelenő európai mutatóra is (Digital Economy and Society Index, DESI ${ }^{14}$ ). Az összetett mérőszámot az Európai Bizottság Tartalmak, Technológiák és Kommunikációs Hálózatok Főigazgatósága (DG CONNECT) dolgozta ki az EU tagállamaiban a digitális gazdaság és a digitális társadalom fejlettségének aktuális szintjének felmérésére a Digitális Menetrend elörehaladását nyomon követendő. A mutató öt tényező (pillér) szerint összesíti a kiválasztott (2017-ben 31, 2018-ban már összesen $34^{15}$ ) indikátorokat: az összekapcsoltság (Connectivity), a humán tőke (Human Capital), az internethasználat (Use of Internet), a digitális technológiák integráltsága (Integration of Digital Technology) és a digitális közszolgáltatások (Digital Public Services). Az indikátorok döntő többségét a tagállamok statisztikai hivatalainak rendszeres adatgyüjtései, illetve a hírközlési hatóságok szolgáltatják, de az olyan, tanácsadó cégek által végzett felmérések eredményeit is felhasználják, mint a korábban ismertetett e-közigazgatási felmérés. A különböző pillérek és indikátorok eltérő súllyal (amelyek az indexalkotók és így a közösség szakpolitikai preferenciáit tükrözik) szerepelnek a végső index eredményében. A digitális közszolgáltatások pillért (az internethasználat pillérhez hasonlóan) a legkisebb, 15\% súllyal veszik figyelembe az index összeállítása során.

A DESI index meglehetősen nagy publicitást kap, és egyfajta zsinórmértékül szolgál a tagállamok megitélése szempontjából az információs társadalom fejlettségének területén (alkalmasint sokkal nagyobbat, mint az összehasonlító felmérésben szereplő adatok és eredmények, amely ez utóbbi bonyolult módszertana és az ebből következő, némileg obskúrus jellege miatt talán nem is meglepő). Vélhetően a DG CONNECT egyik kimondatlan célja is az volt a DESI megalkotásával, hogy az addig használatos, a kitüzött célokat indikátoronként értékelő eredménytábla mellett (Digital Agenda Scoreboard) legyen egy jobban kommunikálhatóbb, a témakörre a figyelmet jobban felhívó mutatórendszer (amit adott esetben a Közösségi források elosztása során is felhasználhat, pozíciója erősítése érdekében). Ezt a feltételezett célt mindenképpen elérte a DESI, mely széles körben idézetté vált, valamint a döntéshozók figyelmét is ráirányította a digitális ökoszisztéma mérhetőségének problematikájára. ${ }^{16}$

\footnotetext{
${ }^{13}$ http://eugo.gov.hu/

${ }^{14}$ https://ec.europa.eu/digital-single-market/en/desi

${ }^{15} \mathrm{http}$ ://ec.europa.eu/information_society/newsroom/image/document/2018-20/desi_2018_indicator_list_46C06BA8-DA78-F7E6-8F21E0AF9FF33C2E_52296.pdf

${ }^{16}$ Ennek példája hazánkban a 2017 végén, a Kormányzati Informatikai Fejlesztési Ügynökség (KIFÜ) és a Digitális Jólét Program (DJP) által kezdeményezett, a BellResearch és az eNet által elvégzett kutatás a digitális ökoszisztéma mérőszámainak pontosításáról, melynek középpontjában szintén a DESI állt (BellResearch és eNet, 2018).
} 
Jelen tanulmánynak nem célja a DESI értékelése, de mindenképpen érdemes az ötödik, digitális közszolgáltatások pillér mentén áttekinteni az index erősségeit és gyengeségeit, valamint használhatóságát az elektronikus közigazgatás területén. A digitális közszolgáltatások mutatóban Magyarország kimondottan rosszul szerepel, 28 tagállam közül a 27. helyet foglalja el a 2018 májusában kiadott legfrissebb adatok alapján (a teljes indexet tekintve hazánk a 23. helyet foglalja el). A DESI index digitális közszolgáltatások pillérét 2018-ban mindösszesen öt indikátor figyelembevételével alakították ki (4. táblázat). ügy az index első kiadásában két indikátorral szerepelt ugyan, de azután megbízható adatforrás hiányában kikerült, és 2018-ban bukkant fel ismét. Ennek hátterében az a törekvés állhat, hogy ne csak a közigazgatási ügyintézés szempontjai szerepeljenek a mutatóban, ám ezen a területen eddig hiányzott a megfelelő minőségü indikátor (ami a módszertanra ható tényezők közül egy újabbra hívja fel a figyelmet).

Korábban volt szó arról, hogy a mutatók folyamatos karbantartása, frissítése kiemelt fontosságú a validitás megőrzése érdekében. Ha áttekintjük a digitális köz-

\begin{tabular}{|l|l|}
\hline $\begin{array}{l}\text { 1. e-Közigazgatási } \\
\text { szolgáltatásokat használók } \\
\text { aránya }\end{array}$ & $\begin{array}{l}\text { Az elektronikus úton hivatalos ürlapot beküldők aránya az utóbbi egy évben } \\
\text { (az internethasználók körében, forrása az Eurostat, a hazai adatokat a KSH szolgáltatja. } \\
\text { A kérdés önbevalláson alapul, tehát a válaszadó percepcióján múlik, hogy mit tekint } \\
\text { hivatalos ürlapnak.) }\end{array}$ \\
\hline 2. Elöre kitöltött ürlapok & $\begin{array}{l}\text { Azoknak az adatoknak a mennyisége, amelyeket az online ürlapokon automatiku- } \\
\text { san kitöltenek (Forrása az eGovernment Benchmark ,Eredeti adatforrások/Authentic } \\
\text { sources” kulcstényezője) }\end{array}$ \\
\hline 3. Online szolgáltatás-teljesség & $\begin{array}{l}\text { A lépések száma, amelyek elektronikusan elvégezhetők egy élethelyet kapcsán } \\
\text { (Forrása az eGovernment Benchmark Ügyfél-központúság indikátorának online } \\
\text { elérhetőség alindikátora) }\end{array}$ \\
\hline 4. Nyílt adatok & $\begin{array}{l}\text { Nyílt adatok fejlettségi indikátor. Az Európai Unió Nyílt Adatok Portálja által } \\
\text { készített összetett mutatószám (többek között a nyílt adatokkal kapcsolatos politikákat } \\
\text { (pl. a PSI irányelvnek történő megfelelést), a nyílt adatok becsült politikai, társadalmi } \\
\text { és gazdasági hatását, valamint a tagállamok adatportáljainak jellemzöit összegzi. }\end{array}$ \\
\hline $\begin{array}{l}\text { 5. e-Egészségügyi } \\
\text { szolgáltatások }\end{array}$ & $\begin{array}{l}\text { e-Egészségügyi szolgáltatások használói. A 2018-ban bevezetett indikátor azt } \\
\text { mutatja, hogy a lakosság mekkora hányada használt online egészségügyi } \\
\text { szolgáltatásokat, elkerülve így a direkt fizikai kontraktust orvosával } \\
\text { (pl. e-recept használata, online konzultáció). (Forrása az Eurobarometer kutatása) }\end{array}$ \\
\hline
\end{tabular}

4. táblázat A DESI Digitális Közszolgáltatások pillérének indikátorai az index 2018-as kiadásában (Európai Bizottság, 2018a)

Egy index esetén az egységes, átgondolt és áttekinthető módszertan kiemelkedő fontosságú. A 2018-as értékek megalkotásában az első négy indikátor azonos súllyal szerepel a mutató megkonstruálása során, és egy külön alpillért alkot, mely a digitális közszolgáltatások értékének 80\%-át adja, míg az egyetlen e-egészségügyi mutató egy másik alpillért alkot 20 százalékos súllyal. Összességében látható, hogy az elektronikus közigazgatás a hagyományosnak tekinthető logikát követve annak mindhárom fontosnak tartott összetevöjét egy-egy indikátorral igyekezett megjeleniteni: a felhasználói oldalt, a kínálatoldalt (vagyis klasszikusan a korábbi összehasonlító értékelésböl ismert megközelítést), illetve a háttérrendszereket is (amelyek felhasználó-szemszögből történő megítélhetősége kérdéses). Ez utóbbi kettőt az eGovernment Benchmark két indikátora adja, tehát az előző fejezetben ismertetett módszertannal felvett értékeket használja fel újra (korábban a 2. táblázatban szürke háttérrel jelzett két almutató). A nyílt adatokra vonatkozó indikátort 2016ban tették a pillér részévé. Ezen a lépésen jól látható, hogy az indexek milyen mértékben követhetik a politikai prioritásokat és az aktuális trendeket is, hiszen a nyílt adatok csak közvetve köthetők a hagyományos értelemben vett közszolgáltatásokhoz. Az e-egészség- szolgáltatások pillér időszakos változásait az elmúlt öt évben, akkor elmondhatjuk, hogy ezt a törekvést túlzásba is lehet vinni, bár a folyamatos módszertani átalakítások hátterében a finomhangolás, illetve a megbízható, érvényes és idősorosan rendelkezésre álló adatforrások integrálása áll, az áttekinthetőség és az értelmezés tartománya jelentősen csökkenhet a konstans változásnak köszönhetően. Az 5. táblázatban feltűntettük az indikátorok eredeti elnevezését, az alpillérek (5a és 5b) súlyát, valamint azok mértékegységét, illetve az adatok egységesítésére használt min-max normalizációs eljárás során használt minimum és maximum értékeket. Az adatokat áttekintve láthatjuk, hogy eddig minden évben változott az index módszertana, tehát a digitális közszolgáltatás mutató minden évben más tartalomból állt össze. Ebböl következik az is, hogy a konkrét értékek idősorosan nem összevethetők. Az első évben még szereplő e-egészségügy indikátorok 2016ra kikerültek a pillérből, így összesen egyetlen (eGovernment) alpillérből állt a következő három évben a pillér eredménye. 2017-ben az alkalmazott indikátorok megmaradtak, de a négyből három esetben megváltozott a normalizációs minimum vagy maximum érték. A 2018-as DESI újra két alpillért tartalmaz (bár az első évtől eltérően az új alpillér csak egy indikátort tartal- 
maz, és mindössze 20\%-os súllyal szerepel). Mindeközben a sokáig változatlan felhasználói indikátor is megváltozott: ezúttal az internethasználók között nem azoknak az arányát mutatja, akik elektronikusan küldtek be ürlapot, hanem azon internetezők között mutatja ezt az arányt, akik adott évben kötelezettek voltak ürlap beküldésére. Az értelmezést mindenképpen nehezíti, hogy ezek a változások sok esetben csak módszertani dokumentumok alapos áttanulmányozásával nyomozhatók ki, de ez utóbbi indikátorváltozásról a hivatalos módszertani jegyzet sem tesz emlitést (Európai Bizottság, 2018a), viszont a magyar országjelentés egy lábjegyzetben tájékoztat arról, hogy az indikátor forrása megváltozott (Európai Bizottság, 2018b).

A folyamatos módszertani változtatások miatt egy ország adott évi eredményét a következő évben az új módszertan szerint korrigálták, így gyakorlatilag az adott évben megjelent két érték hasonlítható össze, az országok pontszámai mellett sokszor (noha nem drasztikus mértékben) a helyezéseik is megváltozhatnak. A 6. táblázatban Magyarország példáján mutatjuk be ezt a gyakorlatot (2015-ben a 2014-es évre vonatkozó indexértékeket is kiszámították).

Az eddigiekből látható, hogy az adatok megfelelő

\begin{tabular}{|c|c|c|c|c|c|c|c|c|c|c|c|c|}
\hline & $\begin{array}{c}2015 \\
\text { indikátorok }\end{array}$ & súly & $\begin{array}{c}\text { m. e. és } \\
\text { min-max } \\
\text { norm. } \\
\text { értékek }\end{array}$ & $\begin{array}{c}2016 \\
\text { indikátorok }\end{array}$ & súly & $\begin{array}{c}\text { m.e. és } \\
\text { min-max } \\
\text { nom. } \\
\text { értékek }\end{array}$ & $\begin{array}{c}2017 \\
\text { indikátorok }\end{array}$ & súly & $\begin{array}{c}\text { m.e. } \\
\text { min-max } \\
\text { nom. } \\
\text { értékek }\end{array}$ & $\begin{array}{c}2018 \\
\text { indikátorok }\end{array}$ & súly & $\begin{array}{c}\text { m.e. } \\
\text { min-max } \\
\text { nom. } \\
\text { értékek }\end{array}$ \\
\hline \multirow{5}{*}{$\begin{array}{l}5 \mathrm{a} . \\
\text { eGo- } \\
\text { ver- } \\
\text { ment }\end{array}$} & $\begin{array}{l}\text { eGovern- } \\
\text { ment users }\end{array}$ & $67 \%$ & $\begin{array}{c}\text { Inter- } \\
\text { nethasz- } \\
\text { nálók } \\
\text { aránya } \\
(0: 80)\end{array}$ & $\begin{array}{l}\text { eGovern- } \\
\text { ment users }\end{array}$ & \multirow{4}{*}{$100 \%$} & $\begin{array}{c}\text { Inter- } \\
\text { nethasz- } \\
\text { nálók } \\
\text { aránya } \\
(0: 80)\end{array}$ & $\begin{array}{l}\text { eGovern- } \\
\text { ment users }\end{array}$ & \multirow{4}{*}{$100 \%$} & $\begin{array}{c}\text { Inter- } \\
\text { nethasz- } \\
\text { nálók } \\
\text { aránya } \\
(0: 100)\end{array}$ & $\begin{array}{l}\text { eGovern- } \\
\text { ment users }\end{array}$ & \multirow{5}{*}{$80 \%$} & $\begin{array}{c}\text { Urlapok } \\
\text { beküldé- } \\
\text { sére kö- } \\
\text { telezett } \\
\text { inter- } \\
\text { nethasz- } \\
\text { nálók } \\
\text { aránya } \\
(0: 100)\end{array}$ \\
\hline & $\begin{array}{l}\text { Pre-filled } \\
\text { forms }\end{array}$ & & $\begin{array}{l}\text { Pont- } \\
\text { szám } \\
(0: 100)\end{array}$ & $\begin{array}{l}\text { Pre-filled } \\
\text { forms }\end{array}$ & & $\begin{array}{l}\text { Pont- } \\
\text { szám } \\
(0: 100)\end{array}$ & $\begin{array}{l}\text { Pre-filled } \\
\text { forms }\end{array}$ & & $\begin{array}{l}\text { Pont- } \\
\text { szám } \\
(0: 100)\end{array}$ & $\begin{array}{l}\text { Pre-filled } \\
\text { forms }\end{array}$ & & $\begin{array}{c}\text { Pont- } \\
\text { szám } \\
(0: 100)\end{array}$ \\
\hline & $\begin{array}{c}\text { Online } \\
\text { service } \\
\text { completion }\end{array}$ & & $\begin{array}{l}\text { Pont- } \\
\text { szám } \\
(0: 100)\end{array}$ & $\begin{array}{l}\text { Online ser- } \\
\text { vice comp- } \\
\text { letion }\end{array}$ & & $\begin{array}{l}\text { Pont- } \\
\text { szám } \\
(0: 100)\end{array}$ & $\begin{array}{c}\text { Online } \\
\text { service } \\
\text { completion }\end{array}$ & & $\begin{array}{c}\text { Pont- } \\
\text { szám } \\
(40: 100)\end{array}$ & $\begin{array}{c}\text { Online } \\
\text { service } \\
\text { completion }\end{array}$ & & $\begin{array}{c}\text { Pont- } \\
\text { szám } \\
(40: 100)\end{array}$ \\
\hline & Open data & & $\begin{array}{l}\text { pont- } \\
\text { szám } \\
(0: 700)\end{array}$ & Open data & & $\begin{array}{l}\text { Pont- } \\
\text { szám } \\
(0: 700)\end{array}$ & Open data & & $\begin{array}{l}\text { A ma- } \\
\text { ximális } \\
\text { pont- } \\
\text { szám } \\
\text { arányá- } \\
\text { ban vett } \\
\text { érték } \\
(0: 100)\end{array}$ & $\begin{array}{c}\text { Digital } \\
\text { Public Ser- } \\
\text { vices for } \\
\text { Businesses }\end{array}$ & & $\begin{array}{c}\text { Pont- } \\
\text { szám } \\
(20: 100)\end{array}$ \\
\hline & & & & & & & & & & Open data & & $\begin{array}{l}\text { A ma- } \\
\text { ximális } \\
\text { pont- } \\
\text { szám } \\
\text { aránya } \\
(0: 100)\end{array}$ \\
\hline \multirow{2}{*}{$\begin{array}{l}5 b . \\
\text { eHealth }\end{array}$} & $\begin{array}{c}\text { Medical } \\
\text { Data ex- } \\
\text { change }\end{array}$ & $33 \%$ & $\begin{array}{l}\text { orvosok } \\
\text { ará- } \\
\text { nyában } \\
(0: 100)\end{array}$ & & & & & & & $\begin{array}{l}\text { eHealth } \\
\text { services }\end{array}$ & \multirow{2}{*}{$20 \%$} & $\begin{array}{c}\text { La- } \\
\text { kosság } \\
\text { aránya } \\
(0: 100)\end{array}$ \\
\hline & $\begin{array}{l}\text { ePrescrip- } \\
\text { tion }\end{array}$ & & $\begin{array}{c}\text { orvosok } \\
\text { ará- } \\
\text { nyában } \\
(0: 100)\end{array}$ & & & & & & & & & \\
\hline
\end{tabular}

5. táblázat A DESI Digitális Közszolgáltatások pillérének összetevői és számítási módjának változásai (dőlt betűvel) az index bevezetése óta (Európai Bizottság, 2018a, 2017b, 2016c) 


\begin{tabular}{|c|c|c|c|c|c|c|c|c|}
\hline & $\begin{array}{l}\text { DESI } \\
2014\end{array}$ & $\begin{array}{l}\text { DESI } \\
2015\end{array}$ & $\begin{array}{c}\text { DESI } \\
2015 \\
\text { korrigált }\end{array}$ & $\begin{array}{l}\text { DESI } \\
2016\end{array}$ & $\begin{array}{c}\text { DESI } \\
2016 \\
\text { korrigált }\end{array}$ & $\begin{array}{l}\text { DESI } \\
2017\end{array}$ & $\begin{array}{l}\text { DESI } \\
2017 \text { kor- } \\
\text { rigált }\end{array}$ & DESI 2018 \\
\hline $\begin{array}{l}\text { Digitális közszolgáltatások } \\
\text { pillér }\end{array}$ & & $\begin{array}{c}0,27 \\
(26 . \text { hely) }\end{array}$ & $\begin{array}{c}0,37 \\
(24 . \text { hely) }\end{array}$ & $\begin{array}{c}0,4 \\
\text { (25. hely) }\end{array}$ & $\begin{array}{c}0,33 \\
\text { (24. hely) }\end{array}$ & $\begin{array}{c}0,35 \\
(27 . \text { hely) }\end{array}$ & $\begin{array}{c}33,6 \\
(27 . \text { hely) }\end{array}$ & $\begin{array}{c}40,4 \\
\text { (28. hely) }\end{array}$ \\
\hline $\begin{array}{l}\text { e-Közigazgatási } \\
\text { szolgáltatások felhasználói }\end{array}$ & $\begin{array}{c}23 \% \\
\text { (17. hely) }\end{array}$ & $\begin{array}{c}31 \% \\
\text { (16. hely) }\end{array}$ & $\begin{array}{c}31 \% \\
\text { (16. hely) }\end{array}$ & $\begin{array}{c}32 \% \\
\text { (17. hely) }\end{array}$ & $\begin{array}{c}32 \% \\
\text { (17. hely) }\end{array}$ & $\begin{array}{c}30 \% \\
\text { (17. hely) }\end{array}$ & $\begin{array}{c}38 \% \\
\text { (26. hely) }\end{array}$ & $\begin{array}{c}45 \% \\
\text { (24. hely) }\end{array}$ \\
\hline $\begin{array}{l}\text { Ürlapok automatikus } \\
\text { kitöltése }\end{array}$ & $\begin{array}{c}52 \\
\text { (14. hely) }\end{array}$ & $\begin{array}{c}19 \\
\text { (22. hely) }\end{array}$ & $\begin{array}{c}19 \\
\text { (22. hely) } \\
\end{array}$ & $\begin{array}{c}19 \\
\text { (25. hely) } \\
\end{array}$ & $\begin{array}{c}19 \\
\text { (25. hely) } \\
\end{array}$ & $\begin{array}{c}23 \\
\text { (23. hely) } \\
\end{array}$ & $\begin{array}{c}23 \\
(23 . \text { hely) } \\
\end{array}$ & $\begin{array}{c}28 \\
\text { (23. hely) } \\
\end{array}$ \\
\hline $\begin{array}{l}\text { Teljes körű online } \\
\text { ügyintézés }\end{array}$ & $\begin{array}{c}45 \\
\text { (27. hely) }\end{array}$ & $\begin{array}{c}45 \\
(28 . \text { hely) } \\
\end{array}$ & $\begin{array}{c}45 \\
(28 . \text { hely) } \\
\end{array}$ & $\begin{array}{c}55 \\
\text { (26. hely) }\end{array}$ & $\begin{array}{c}55 \\
\text { (26. hely) }\end{array}$ & $\begin{array}{c}63 \\
(25 . \text { hely) } \\
\end{array}$ & $\begin{array}{c}63 \\
(25 . \text { hely) } \\
\end{array}$ & $\begin{array}{c}75 \\
\text { (25. hely) }\end{array}$ \\
\hline $\begin{array}{l}\text { Vállalkozásoknak nyújtott } \\
\text { digitális közszolgáltatások }\end{array}$ & & & & & & & $\begin{array}{c}68 \\
\text { (23. hely) } \\
\end{array}$ & $\begin{array}{c}73 \\
\text { (24. hely) } \\
\end{array}$ \\
\hline Nyílt hozzáférésű adatok & & $\begin{array}{c}300 \\
\text { (19. hely) }\end{array}$ & $\begin{array}{c}300 \\
\text { (19. hely) }\end{array}$ & $\begin{array}{c}300 \\
\text { (20. hely) }\end{array}$ & $\begin{array}{c}50 \% \\
\text { (11. hely) }\end{array}$ & $\begin{array}{c}43 \% \\
\text { (23. hely) }\end{array}$ & $\begin{array}{c}43 \% \\
\text { (23. hely) }\end{array}$ & $\begin{array}{c}48 \% \\
\text { (26. hely) }\end{array}$ \\
\hline $\begin{array}{l}\text { e-Egészségügyi } \\
\text { szolgáltatások }\end{array}$ & & & & & & & n.a & $\begin{array}{c}7 \% \\
\text { (26. hely) }\end{array}$ \\
\hline $\begin{array}{l}\text { Egészségügyi adatok } \\
\text { elektronikus megosztása }\end{array}$ & $\begin{array}{c}12 \% \\
\text { (23. hely) }\end{array}$ & $\begin{array}{c}12 \% \\
\text { (23. hely) }\end{array}$ & & & & & & \\
\hline eRecept & $\begin{array}{c}2,2 \% \\
\text { (25. hely) }\end{array}$ & $\begin{array}{c}2,2 \% \\
\text { (25. hely) }\end{array}$ & & & & & & \\
\hline
\end{tabular}

6. táblázat Magyarország eredményei a DESI Digitális Közszolgáltatások pillérének tekintetében, $2014-2018$ (Európai Bizottság, 2018b, 2017c, 2016d)

értelmezése, nyomon követése meglehetősen nehézkes, és ezt nem könnyíti meg a módszertani változások kommunikációja sem. Ebből a szempontból a DESI (legalábbis annak digitális közszolgáltatások pillére) egy átfogó, általános kép kialakítására megfelelö, ugyanakkor a döntéshozók számára nem nyújt kellö visszacsatolást, a különbözö mutatókat pozitivivan elöremozdító szakpolitikai intézkedések hatásmechanizmusának részletes követésére (tagállami szinten) nem igazán alkalmas. A digitális közigazgatás pillér esetében az eGovernment Benchmark beható ismerete számos olyan pluszinformációt nyújt, amelyek elengedhetetlenek a (rész)mutató kontextusban történő értelmezéséhez. A korábban látott, az eredeti adatforrásokat érintő 2012-es anomália például a 6. táblázatban is tetten érhető, ennek „köszönhetően” csökkent drasztikusan 2014-ről 2015-re az indikátor értéke, és zuhant (látszólag) jelentősen Magyarország teljesítménye egyik évröl a másikra. Holott csak annyi történt, hogy időközben a páros évek élethelyzeteit ismét értékelték, a problémás (ahol a probléma a felülmérés volt) értékek pedig kikerültek a két év átlagában számított eredményekböl. Ez a gyakorlat rámutat arra is, hogy az eGovernment Benchmarkhoz kötődő indikátorok esetében (a „hagyományos", évröl-évre történő statisztikai adatfelvételekkel ellentétben) akár bő három évig is eltarthat egy fejlesztés eredményeinek megjelenése, és a más élethelyzetekkel történő összevonás eredményeként ez a hatás sem lesz feltétlenül jelentős. Szintén érdekes a magyar eredmények szempontjából is, hogy a 2018-as DESI értékekben a 2017-ben megjelent, a 2016-os adatfelvételre támaszkodó adatok szerepelnek, melyek nem összevethetők a korábbi évekkel a módszertan változása miatt. Mivel a magyar eredmények (ahogy azt a 3 . táblázatban is láthattuk) általában a páratlan években értékelt élethelyzetekben alacsonyabbak, a 2017-es értékek számításba vételekor ismét csökkenhetnek a hazai pontszámok. A Bellresearch és az eNet korábban említett kutatása pedig arra is rámutatott, hogy a DESI 2018-as verziójához használt eGovernment Benchmark eredményeket utólag módosították, tehát jelen kézirat lezárásakor ellentmondás feszül a publikus benchmarkeredmények és a DESI-ben elérhető mutatók között (Bellresearch és eNET, 2018, illetve a kutatási jelentés szerzőinek személyes közlése).

Az ilyen és ehhez hasonló anomáliák hívják fel arra a figyelmet, hogy az indexek nagyon jó szolgálatot tesznek, ha süritett, könnyen áttekinthetö formában van szükség általános információkra egy adott területröl. Az ördög azonban, mint mindig, itt is a részletekben rejlik, és a többszörös információ-összevonás, az eredeti kontextusából bizonyos mértékben kiemelt, módszertani finomságaiktól megfosztott indikátorok (melyeket szakmai és politikai célok dinamikusan változó keveréke alakít folyamatosan) olyan következtetések levonására is csábítanak, amelyek nem indokoltak. Nem állítjuk, hogy a DESI és a hasonló indexek tendenciózusan pontatlanok, vagy félrevezetőek lennének, mindössze használatuk során érdemes kellö figyelmet fordítani korlátaikra is, különösen akkor, ha azokhoz szinte explicit módon társul a kvázi-szabályozó szerep, vagyis céljuk részben az adott országok vagy országcsoportok általános fejlettségi állapotának politikai közbeszédben történő hangsúlyozása. 


\section{Összegzés, konklúziók}

A mérhetőség, az értékelés, a befektetett energia és erőforrások hasznosulásának problematikája mindig is foglalkoztatta az emberiséget és nincs ez másként az elektronikus közigazgatás fejlesztésének területén sem. Az e-közigazgatás fejlődésének kezdeti szakaszától kezdve számos különböző értékelés készült, és ezekkel megközelítőleg egyidős ezeknek a mérőrendszereknek a kritikája is. Az e-közigazgatás mérésére számos különböző indikátor használható, de az értékelések általában a kimenet vagy a környezeti típusúakat részesítik előnyben, míg a hatásokat, vagy a befektetéseket számszerüsítő mutatókból és vizsgálatokból jóval kevesebb van, pedig a teljes képhez a fejlesztések és azok társadalmi/gazdasági hatásainak, megtérüléseinek elemzéséhez a különböző típusú indikátorok megfelelő arányú elegye szükséges. Tanulmányunkban a publikusan elérhető módszertani dokumentumok alapján az Európai Unió két olyan mérörendszerét tekintettük át (eGovernment Benchmark és a Digital Economy and Society Index), mint olyan széles körben elterjedt és sokat idézett módszert, amelyek az elektronikus közigazgatás értékelésére leginkább használatosak napjainkban.

Az e-közigazgatási összehasonlító felmérés módszertanát áttekintve az látható, hogy az abban 2010 után bekövetkezett módszertani változtatások sok esetben reflektálnak a mérőrendszert ért korábbi kritikákra: a szolgáltatások szélesebb körét elemzik, a felhasználók szemszögéből életszerübb megközelítésben és tágabb szempontrendszer alapján, ugyanakkor megmaradt az alapvetően a kínálati oldalt vizsgáló megközelítés, ami különösen annak fényében szomorú, hogy a felhasználó oldali eredmények egyrészt sokkal kevésbé függhetnek a technológiai és egyéb változásoktól, másrészt pontosabb képet nyújtanának a szolgáltatások érzékelt minőségéről. Az értékelő szempontrendszer a 2016-os módszertani felülvizsgálat során minimálisan alakult át, elsősorban a technológiai fejlődésre reflektálva (mobileszközök vizsgálata), valamint az értékelési kategóriák finomítása érdekében (néhány esetben új kérdések, alszempontok szerepeltetése), ugyanakkor ezeknek a változásoknak az új e-közigazgatási akciótervhez történő kapcsolása leginkább szimbolikusnak tekinthető. Érdemes megemlítenünk, hogy az ilyen és hasonló mérörendszerek változtatása általában a listán előkelőbb helyet elfoglaló, fejlettebb országoknak kedvez, ami ezen országok esetleges lobbitevékenységén túl valójában természetes folyamat: az új értékelési szempontok általában olyan jellemzőkre, minőségi ismérvekre vonatkoznak, amelyet könnyebb a már magasabb szinten funkcionáló rendszerekbe beépíteni. Az összehasonlító felmérés eredményei értékelésénél és használatánál mindenképpen figyelembe kell venni a kutatás módszertani sajátosságait (tranzakciót nem végző próbaügyintézők, a kétévenkénti adatfelvétel miatt időbeli elnyújtottság), illetve azt, hogy a kibővült szolgáltatáslista ellenére is leginkább olyan területek és ügytípusok kerülnek értékelésre, amelyek a tagállamok különböző közigazgatási hagyományai ellenére zömében összevethetők. Örvendetes tényező a módszertan dokumentáltsága, illetve az eredmények részletes publikálása, így ugyanis azok érdemben használhatók akár szakpolitikai beavatkozások, projektek eredményeinek nyomon követésére is - a pontszámok érdemi felhasználásához azonban kellő módszertani hátország, a felmérés részletes megismerése elengedhetetlen. Ez utóbbi a kvázi-szabályozási funkció, a mérési-módszertannak történő kényszeres megfelelés csapdájának elkerülése szempontjából sem elhanyagolható szempont.

A DESI, illetve az index digitális közszolgáltatások alpillérnek elemzése számos, a kompozit indexek kapcsán általánosan elmondható dilemmát vetett fel (lásd például OECD, 2008), kezdve a megfelelő indikátor kiválasztástól (illetve az indikátorkészlet frissítésétől) a súlyozás és normalizáció kérdésein át az eredmények prezentációjáig. A DESI mindenképpen alkalmas egy általános kép felrajzolására egy ország, vagy országcsoport digitális fejlettségéröl, de a digitális közszolgáltatások pillérnél bemutatott sajátosságai, illetve néhol hiányosságai alapján (ilyenek például a folyamatosan változó módszertan miatt az idősoros elemzés problematikus, az indikátorokban több éves csúszás halmozódik fel, bizonyos esetekben a módszertan nem megfelelően dokumentált), viszont az eredményeket érdemes a helyükön (és a mérőeszköz által mérni kívánt szakpolitika kontextusában) kezelni. Nem érdemes elveszni az országranglisták popzenei toplistákhoz hasonlatos méricskélésében, hiszen az összetett mérőszámok és az ezek alapján összeállított relatív országrangsorok magukban hordozzák a túlzott általánosítás és az információvesztésből adódó anomáliák lehetőségét is. Az 1-2 (5-6) helyezésnyi elmozdulásokról szóló „viták” érintetlenül hagyják a mérések valódi lényegét és esetleges hasznát.

Mindezek alapján elmondható, hogy az ismertetett méröszámok értő használata segítségül szolgálhat a döntéshozó számára. A szakirodalommal összhangban szintén állítható, hogy fontos ezeknek a mérörendszereknek a folyamatos módszertani fejlesztése, a mindennapokhoz és a valós viszonyokhoz alakítása mind az indikátorok összeválogatása, mind pedig pontos meghatározásuk és mérésük során. Legalább ennyire fontos ugyanakkor a változás megfelelő menedzsmentje, illetve annak kommunikálása is, amiben az európai módszertanok készítői sem mindig teljesítenek hibátlanul, ami erősítheti azt a kritikai véleményt, hogy a mérörendszerek legalább annyira a nyomásgyakorlás, mint az érdemi visszacsatolás eszközei. Pedig ahhoz, hogy az adatok valóban segítsék az előrehaladást, a mérés tárgyára hatással lévő döntéshozók szemszögéből az okok és következmények feltárásához, illetve valós fejlesztési irányok és részterületek meghatározásához a részletes adatok szolgáltathatnak kellő információt, de csak akkor, ha ezek a döntéshozók ismerik a mérések kontextusát, fogalomhasználatát, előnyeit és esetleges korlátait is.

\section{Felhasznált irodalom}

ANAO (1999): Electronic service delivery, including internet use by Commonwealth Government Agencies. Canberra: Australian National Auditing Office. https:// www.anao.gov.au/work/performance-audit/electro- 
nic-service-delivery-including-internet-use-commonwealth-government

Antal, Zs. (2018): A közszolgálati kommunikáció eredményességére ható tényezők. A közszféra és a versenyszféra kommunikációs gyakorlatát befolyásoló különbségek. Vezetéstudomány/Budapest Management Review, 49 (4), p. 68-76. https://doi.org/10.14267/veztud.2018.04.07

Bannister, F. (2007): The curse of the benchmark: an assessment of the validity and value of e-government comparisons. International Review of Administrative Sciences, 73(2), p. 171-188. https://doi. org $/ 10.1177 / 0020852307077959$

BellReaserch \& eNet (2018): A digitális ökoszisztéma mérőszámainak pontosítása - kutatási összefoglaló.

Budai, B. (2009): Az e-közigazgatás elmélete. Budapest: Akadémiai Kiadó

Capgemini Ernst \& Young (2001): Summary report webbased survey on electronic public services: Results of the first measurement. Brussels: European Commission, DG Information Society

Codagnone, C. - Undheim, T. (2008): Government efficiency and effectiveness: The theory and practice of benchmarking and measurement. European Journal of e-Practice, 1(4), p. 4-18.

Codagnone, C. - Misuraca, G. - Savoldelli, A. - LupiañezVillanueva, F. (2015): Institutional isomorphism, policy networks, and the analytical depreciation of measurement indicators: The case of the EU. Telecommunications Policy, 39(3-4), p. 305-319. https://doi. org/10.1016/j.telpol.2015.01.005

Csótó, M. (2017): Az e-közigazgatási szolgáltatások további terjedésének lehetőségei Magyarországon. Kézirat (Benyújtva: Pro Publico Bono - Magyar Közigazgatás)

Deming, W. E. (1986): Out of the crisis. Cambridge, MA: Massachusetts Institute of Technology

Európai Bizottság (2001): eGovernment indicators for benchmarking eEurope. http://ec.europa.eu/newsroom/dae/document.cfm?doc_id=1189

Európai Bizottság (2010): eGovernment Action Plan 2011-2015 http://ec.europa.eu/information_society/ activities/egovernment/action_plan_2011_2015/index_en.htm

Európai Bizottság-CapGemini (2013): Public services online 'digital by default or by detour?'Assessing user centric eGovernment performance in Europe - eGovernment Benchmark 2012 : final background report. https://publications.europa.eu/en/publication-detail/-/ publication/729cc5cd-fd96-4b4d-b427-8801d216a94e

Európai Bizottság (2015a): eGovernment Benchmark Framework 2012-2015. Method Paper Update. http://ec.europa.eu/newsroom/dae/document. cfm?action=display\&doc id $=10036$

Európai Bizottság (2015b): DESI 2015. Methodological note. https://m.itcafe.hu/dl/cnt/2015-02/116080/desimodszertan.pdf

Európai Bizottság (2016a): eGovernment Benchmark Method. An update for a new cycle 2016-
2019. http://ec.europa.eu/newsroom/dae/document. cfm?action=display\&doc_id=17858

Európai Bizottság (2016b): Country Factsheets - eGovernment Benchmark Report 2016, Hungary

Európai Bizottság (2016c): DESI 2016. Methodological note http://ec.europa.eu/newsroom/dae/document. cfm?doc_id=8846

Európai Bizottság (2016d): A digitális gazdaság és társadalom fejlettségét mérő mutató (DESI), 2017, Magyarországról szóló országjelentés. http://ec.europa. eu/newsroom/dae/document.cfm?doc_id=14126 http:// ec.europa.eu/newsroom/dae/document.cfm?doc $\mathrm{id}=17873$

Európai Bizottság (2017a): eGovernment Benchmark 2016 Source Data. http://ec.europa.eu/newsroom/dae/document.cfm?doc_id=48589

Európai Bizottság (2017b): DESI 2017. Methodological note. http://ec.europa.eu/newsroom/document. cfm?doc_id=43048

Európai Bizottság (2017c): A digitális gazdaság és társadalom fejlettségét mérő mutató (DESI), 2017, Magyarországról szóló országjelentés. http://ec.europa.eu/ newsroom/document.cfm?doc id $=43017$

Európai Bizottság (2018a): DESI 2018. Methodological Note. http:/ec.europa.eu/information_society/newsroom/image/document/2018-20/ desi-2018-methodology_E886EDCA-B32A-AEFB07F5911DE975477B_52297.pdf

Európai Bizottság (2018b): A digitális gazdaság és társadalom fejlettségét mérő mutató (DESI), 2018, Magyarországról szóló országjelentés. http://ec.europa.eu/information_society/newsroom/image/document/2018-20/ hu-desi_2018-country-profile-lang_4AA43283-EC48996F-09918493E34A691F_52334.pdf

Európai Parlament és Tanács (2006): 2006/123/ EK Irányelv a belső piaci szolgáltatásokról. https://eur-lex.europa.eu/legal-content/HU/ TXT/?uri=celex:32006L0123

Fernández-i-Marín, X. (2011): The Impact of e-Government Promotion in Europe: Internet Dependence and Critical Mass. Policy \& Internet, 3(4), p. 1-29. https:// doi.org/10.2202/1944-2866.1093

Janssen, D. - Rotthier, S. - Snijkers, K. (2004): If you measure it they will score: An assessment of international eGovernment benchmarking. Information Polity, $9(3,4)$, p. 121-130.

Kemény, I. (2017): Az elektronikusszolgáltatás-minőség értékelése a pénzügyi szolgáltatások online vásárlása esetében. Vezetéstudomány/Budapest Management Review, 48 (2), p. 15-29. https://doi.org/10.14267/VEZTUD.2017.02.02

Kenesei, Zs. - Seprődi, P. (2017): Service experience design, avagy a szolgáltatások tervezésének új kihívásai. Vezetéstudomány/Budapest Management Review, 48 (2), p. 53-66. https://doi.org/10.14267/VEZTUD.2017.02.05

Keszey, T. - Zsukk, J. (2017): Az új technológiák fogyasztói elfogadása. A magyar és nemzetközi szakirodalom áttekintése és kritikai értékelése. Vezetéstudomány/Bu- 
dapest Management Review, 48 (10), p. 38-47. https:// doi.org/10.14267/VEZTUD.2017.10.05

Kunstelj, M. - Vintar, M. (2004): Evaluating the progress of e-government development: A critical analysis. Information Polity, 9(3, 4), p. 131-148.

Makó, Cs. - Illéssy, M. - Mitchell, B. (2014): Systemic country differences in the European innovation performance - Does institutional context matter? Vezetéstudomány/ Budapest Management Review, 45 (11), p. 2-10.

Misuraca, G. - Codagnone, C. - Rossel, P. (2013): From practice to theory and back to practice: Reflexivity in measurement and evaluation for evidence-based policy making in the information society. Government Information Quarterly, 30 (Supplement 1), p. 68-82. https://doi.org/10.1016/j.giq.2012.07.011

Miszlivetz, F. - Márkus E. (2013): A KRAFT-Index - kreatív városok - fenntartható vidék. Vezetéstudomány/ Budapest Management Review, 44(9), p. 2-21.
Molnár, Sz. (2011): Európai uniós e-közigazgatás jelentés - de minek? eGov Hírlevél, 2011. február 28. http:// hirlevel.egov.hu/2011/02/28/europai-unios-e-kozigazgatas-jelentes- $\% \mathrm{E} 2 \% 80 \% 93$-de-minek/

OECD (2008): Handbook on Constructing Composite Indicators. http://www.oecd.org/sdd/42495745.pdf

Rorissa, A. - Demissie, D. - Pardo, T. (2011): Benchmarking e-Government : A comparison of frameworks for computing e-Government index and ranking. Government Information Quarterly, 28(3), p. 354-362. https:// doi.org/10.1016/j.giq.2010.09.006

Shewhart, W. A. (1986) (1939): Statistical method from the viewpoint of quality control. New York: Dover

Solow, R. (1987): We'd better watch out. New York Times, July 12 , p. 36.

Takács E. (2015): A közszolgálati szervezetek értékelési módszereinek osztályozása. Vezetéstudomány/Budapest Management Review, 46(3), p. 45-56. 